\title{
Differential Expression of Two Soybean Apyrases, One of Which Is an Early Nodulin
}

\author{
R. Bradley Day, ${ }^{1}$ Crystal B. McAlvin, ${ }^{1}$ John T. Loh, ${ }^{1}$ Roxanne L. Denny, ${ }^{2}$ Todd C. Wood, ${ }^{4}$ \\ Nevin D. Young, ${ }^{2,3}$ and Gary Stacey ${ }^{1}$ \\ ${ }^{1}$ Center for Legume Research, Department of Microbiology, University of Tennessee, Knoxville 37996, \\ U.S.A.; ${ }^{2}$ Department of Plant Pathology and ${ }^{3}$ Department of Plant Biology, University of Minnesota, \\ St. Paul 55108, U.S.A.; ${ }^{4}$ Clemson University Genomics Institute, Clemson University, Clemson, SC, \\ 29634, U.S.A. \\ Accepted 13 June 2000.
}

Two cDNA clones were isolated from soybean (Glycine soja) by polymerase chain reaction with primers designed to conserved motifs found in apyrases (nucleotide phosphohydrolase). The two cDNAs are predicted to encode for two, distinct, apyrase proteins of approximately $50 \mathrm{kDa}$ (i.e., GS50) and 52 kDa (i.e., GS52). Phylogenetic analysis indicated that GS52 is orthologous to a family of apyrases recently suggested to play a role in legume nodulation. GS50 is paralogous to this family and, therefore, likely plays a different physiological role. Consistent with this analysis, GS50 mRNA was detected in root, hypocotyls, flowers, and stems, while GS52 mRNA was found in root and flowers. Neither gene was expressed in leaves or cotyledons. Inoculation of roots with Bradyrhizobium japonicum, nitrogen-fixing symbiont of soybean, resulted in the rapid $(<6 \mathrm{~h})$ induction of GS52 mRNA expression. The level of GS50 mRNA expression was not affected by bacterial inoculation. Western blot (immunoblot) analysis of GS50 expression mirrored the results obtained by mRNA analysis. However, in contrast to the mRNA results, GS52 protein was found in stems. Interestingly, anti-GS52 antibody recognized a 50-kDa protein found only in nodule extracts. Treatment of roots with antiGS52 antibody, but not anti-GS50 antibody or preimmune serum, blocked nodulation by $\boldsymbol{B}$. japonicum. Fractionation of cellular membranes in sucrose density gradients and subsequent Western analysis of the fractions revealed that GS50 colocalized with marker enzymes for the Golgi, while GS52 colocalized with marker enzymes for the plasma membrane. Restriction fragment length polymorphism (RFLP)-based mapping placed the gs52 gene on major linkage group $\mathrm{J}$ of the integrated genetic map of soybean. These data suggest that GS50 is likely an endo-apyrase involved in Golgi function, while GS52 is localized on the root surface and appears to play an important role in nodulation.

Corresponding author: Gary Stacey, Department of Microbiology, M409 Walters Life Science Bldg., University of Tennessee, Knoxville 379960845, U.S.A.; Telephone: 1-865-974-4041; Fax: 1-865-974-4007; Email: gstacey@utk.edu

Nucleotide and/or amino acid sequence data have been deposited at the GenBank data base as accession numbers AF207687 and AF207688.
Apyrases (nucleotide phosphohydrolases) can be divided into two main classes: ecto-apyrases and endo-apyrases. Ectoapyrases are characterized as having the catalytic domain outside of the cell, whereas endo-apyrases have the catalytic domain inside the cell (Komoszynski and Wojtczak 1996). Apyrases have been proposed to function in such diverse roles as neurotransmission (Edwards and Gibb 1993), blood platelet aggregation (Marcus and Safier 1993), and protein glycosylation in the Golgi lumen (Abeijon et al. 1993; Gao et al. 1999). In Saccharomyces cerevisiae, glycosylation of $\mathrm{N}$ - and $\mathrm{O}-$ linked oligosaccharides in the Golgi is thought to be regulated, in part, by the action of two endo-apyrases, encoded by the gdal and yndl genes, that convert GDP (released by hydrolysis of GTP-sugar) to GMP (Abeijon et al. 1993; Gao et al. 1999). The GMP exits the Golgi through an antiport system that allows GTP-sugar import. A double mutant defective in both GDA1p and YND1p function exhibits very slow growth and severe defects in protein glycosylation and cell wall integrity (Gao et al. 1999). An interesting function for ectoapyrases in animals is at the synaptic junctions of nerve cells (Komoszynski and Wojtczak 1996; Sarkis and Salto 1991). Here, an ecto-apyrase degrades extracellular ATP to AMP. This process releases the purinoreceptors due to their lower affinity for AMP. By modulating the level of ATP + ADP/AMP, apyrases also affect 5 '-nucleotidase, an abundant enzyme in the synaptic space, which is inhibited by ADP and ATP but activated by AMP. The final product of apyrase and 5'-nucleotidase action is adenosine, which penetrates cell membranes where it is phosphorylated, restoring the cellular ATP pool. Adenosine also has the effect of stimulating adenyl cyclase, causing an increase in cyclic AMP (cAMP). Thus, apyrase activity can affect synaptic junction activity in many ways.

In plants, an apyrase present in pea (Pisum sativum) has been studied for a number of years as a calmodulin-stimulated, nuclei-localized NTPase that was originally proposed to be involved in mediating phytochrome responses (Chen and Roux 1986; Chen et al. 1987). Hsieh et al. (1996) examined the differential expression of the pea apyrase in various organs, and found that mRNA was expressed in root tissues of light-grown plants and also in dark-grown plumules, stems, and roots, but not in leaves and stems of light-grown plants. Recently, Thomas et al. (1999) extended the functional analysis of the pea NTPase/apyrase and demonstrated that trans- 
genic expression of the pea apyrase in Arabidopsis thaliana resulted in plants that showed enhanced growth and augmented phosphate transport when supplied as inorganic phosphate or as ATP.

Recently, Etzler et al. (1999) reported on a unique lectin (DB46) isolated from the roots of the legume Dolichos biflorus. The $D$. biflorus lectin was found to bind to the lipo-chitin Nod signals from a variety of rhizobia. These lipo-chitin Nod signals are produced by rhizobia and induce de novo organogenesis on the compatible host leading to the formation of a nodule structure in which the bacteria reside and fix nitrogen (Cohn et al. 1998). Etzler et al. (1999) showed that DB46 had the highest apparent affinity for the Nod signal produced by Bradyrhizobium japonicum and Rhizobium sp. strain NGR234, bacteria that can nodulate D. biflorus. Sequence comparisons revealed that the $D$. biflorus lectin was likely an apyrase (i.e., NTPase). Indeed, Etzler et al. (1999) demonstrated that DB46 did possess ATPase activity, which was significantly enhanced upon addition of the Nod signal. For this reason, the lectin was termed a lectin-nucleotide phosphohydrolase (LNP). The D. biflorus LNP (i.e., DB46) was found on the surface of root hairs by fluorescent antibody labeling. Moreover, pretreatment of the roots of $D$. biflorus with antiLNP antibodies inhibited nodulation by its rhizobial symbiont. These data suggest that LNP is an ecto-apyrase. Based on their results, Etzler et al. (1999) postulated that LNP could play a role in the recognition of the lipo-chitin Nod signal with transduction of this binding signal mediated by activation of apyrase enzyme activity.

A variety of physiological responses are elicited in the legume host in response to the compatible rhizobium or Nod signal. Among these responses is the induction of transcription of a variety of plant genes (termed nodulins) associated with the onset and progression of nodulation (reviewed in Bladergroen and Spaink 1998). Depending upon their time of activation, these genes can be classified as early or late nodulins. Classical examples of early nodulins, which are induced within $48 \mathrm{~h}$ of inoculation, include enod2, enod12, and enod40 (Scheres et al. 1990; Pichon et al. 1992; Kouchi and Hata 1995). Among the most rapidly induced early nodulins is RIP1 (rhizobiuminduced peroxidase), which is induced in Medicago truncatula within $3 \mathrm{~h}$ of inoculation with the compatible symbiont, Sinorhizobium meliloti (Cook et al. 1995). Examples of genes classified as late nodulins are those that encode leghemoglobin and uricase (Papadopoulou et al. 1995; Heidstra et al. 1997). Originally defined as nodule-specific genes, it is now recognized that, although nodulin expression is enhanced during nodulation, nodulin gene products can also be found in other plant organs. For example, ENOD40 is expressed during nodulation and is also found in flowers (Crespi et al. 1994). Indeed, nodulin homologues have been identified in nonlegume species (e.g., Kouchi et al. 1999).

Due to their postulated role as receptors for the Nod signals made by rhizobia, we initiated a study of the apyrases found in soybean. In this report, we describe the characterization of two cDNAs encoding proteins, GS50 and GS52, that clearly fall within the apyrase protein family. The mRNAs encoded by these cDNAs are differentially expressed in different soybean tissue. Similar to early nodulin genes, mRNA encoding GS52 is rapidly induced in roots inoculated by the compatible soybean symbiont, B. japonicum. Antibody produced to re- combinant GS50 and GS52 was used to determine the cellular localization of these proteins. The data showed that GS50 is an endo-apyrase, while GS52 is likely an ecto-apyrase. Treatment of roots with antibody directed against GS52 was found to inhibit nodulation. These data suggest that GS52 may play an important role in the soybean nodulation response.

\section{RESULTS}

\section{Identification of two soybean cDNAs encoding putative apyrase genes.}

Two soybean apyrase cDNAs were identified by touch down-polymerase chain reaction (TD-PCR) (Don et al. 1991) with primers designed to a conserved catalytic domain found in a variety of apyrases. The 850-bp ( $g s 50)$ (pDAY15) and 351-bp (gs52) (pDAY9) partial cDNAs isolated with TD-PCR were extended with rapid amplification of cDNA ends (RACE)PCR (Frohman et al. 1988) to yield two full-length cDNA sequences. To guard against the possibility of errors introduced during the PCR amplification, two clones were independently generated from each end, and both strands were completely sequenced. Isolation of the full-length cDNA clones was performed with PCR with Pfu DNA polymerase and primers complementary to the $3^{\prime}$ and $5^{\prime}$ ends of $g s 50$ and gs52. This approach yielded plasmids pDAY46-A ( $g s 50)$ and pDAY46new (gs52) containing the full-length cDNA clones. The sequence of gs50 (GenBank accession number AF207687) predicts an open reading of 463 amino acids, encoding a protein with an apparent molecular weight of 50,800. The sequence of the gs52 cDNA (GenBank accession number AF207688) predicts an open reading frame of 468 amino acids encoding a protein with an apparent molecular weight of 51,600.

We identified homologues of GS50 and GS52 from a BLASTP search of the NCBI nonredundant protein sequence data base (Altschul et al. 1997). Additional homologues were identified from dbEST with TFASTX3 (Pearson et al. 1997). Our alignment of full-length GS50, GS52, and other known apyrases shows the conserved catalytic motifs characteristic of this protein family (Fig. 1). Additionally, none of the conserved sites show any similarity to the consensus Walker ATPbinding motifs (Walker et al. 1982).

For phylogenetic analysis, we aligned nine partial sequences of plant apyrases and the yeast protein GDA1. We included translations of a tomato EST (expressed sequence tag; LeEST) and a cotton EST (Gh-EST) in our alignment and phylogeny, since these sequences seemed to have been overlooked in the phylogenetic analysis of Roberts et al. (1999). A neighbor-joining tree generated from this alignment shows that there appear to be at least three subfamilies of apyrases found in plants (Fig. 2). Subfamily A contains GS50, the apyrases from $A$. thaliana and D. biflorus, and the cotton EST. Subfamily B contains GS52 and the LNP sequences from $P$. sativum and $D$. biflorus. Subfamily C contains the $S$. tuberosum apyrase and the tomato EST.

Hydropathy plot analysis was performed with MegAlign sequence analysis software (DNASTAR, Madison, WI, U.S.A.) (data not shown). The complete deduced amino acid sequence of GS50 showed only one predicted transmembrane segment at residues 1 to 22. Interestingly, hydropathy analysis of GS52 also suggested the presence of single transmembrane segment. However, PSORT analysis (Nakai and Kanehisa 1991) pre- 
dicted the likelihood that GS52 is a peripheral protein, with a cleavable $\mathrm{N}$-terminal signal sequence at amino acid residue 33 . In the case of GS50, the predicted transmembrane segment is 22 amino acids, beginning with methionine. This is characteristic of a hydrophobic signal sequence necessary for translocation across the endoplasmic membrane (von Heijne 1989), therefore suggesting that GS50 might traverse the secretory pathway.

\section{PCR products generated with DNA primers}

to gs50 and gs52 hybridize to genomic DNA from Glycine soja.

To ensure that the $g s 50$ and $g s 52$ cDNA clones isolated by a TD-PCR approach were in fact representative of true DNA se- quences derived from $G$. soja, Southern blot analysis was performed with ${ }^{32} \mathrm{P}$-labeled DNA probes (data not shown). With endonuclease-restricted genomic DNA isolated from $G$. soja, gene-specific DNA probes corresponding to regions of $g s 50$ and gs52 derived from the extreme $5^{\prime}$ and $3^{\prime}$ ends of each cDNA, respectively, were used as probes to enhance the differences in nucleotide sequences. The labeled probes hybridized under stringent conditions with genomic soybean DNA, thus indicating the clones did arise from G. soja sequences and were not the result of contamination during PCR. The gs50 probe hybridized to a $2.2-\mathrm{kb}$ EcoRI fragment, while the gs52 probe hybridized to a 4.1-kb EcoRI fragment. Similarly, both the $g s 50$ and $g_{s} 52$ probes hybridized to an internal HindIII

\begin{tabular}{|c|c|c|c|c|c|}
\hline GS 50 & 52 & ESYAVIE & U/ & VHVYREN & 73 \\
\hline GS 52 & 52 & TSYAVIF & 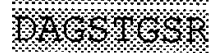 & VHVFHFD & 77 \\
\hline LNP & 52 & TSYAVIF & \% & VHVFNFD & 73 \\
\hline PNTPASE & 42 & SSYAVVE & 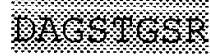 & IHVYHFN & 63 \\
\hline POTATO APYRASE & 44 & EHYAVIF & / & VHVFRFD & 65 \\
\hline GDA1 & 91 & HKYVIMI & / & VHIYKFD & 112 \\
\hline HUMAN CD39 & 47 & VHYGIVL & X/ & LYIYKWP & 68 \\
\hline
\end{tabular}

\begin{tabular}{|c|c|c|c|c|c|c|}
\hline GS50 & 127 & $\mathrm{RT}$ & KLG & W.1.4. & QLEGDAS & 146 \\
\hline GS 52 & 131 & $\mathrm{TT}$ & KLG & Wrot & LLEGDAS & 150 \\
\hline LNP & 117 & $\mathrm{KT}$ & W KLG & 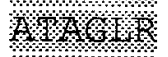 & LLDGDAS & 136 \\
\hline PNTPASE & 118 & $\mathrm{KT}$ & XIG & 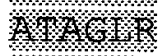 & LLNGDAS & 135 \\
\hline POTATO APYRASE & 120 & $\mathrm{KT}$ & VII ELG & x & MLKGDAS & 140 \\
\hline GDA1 & 165 & $\mathrm{KT}$ & AVK & 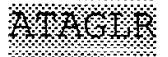 & LL. GDAS & 184 \\
\hline HUMAN CD39 & 124 & $\mathrm{KT}$ & AVK & (2) & LL.GDAS & 143 \\
\hline
\end{tabular}

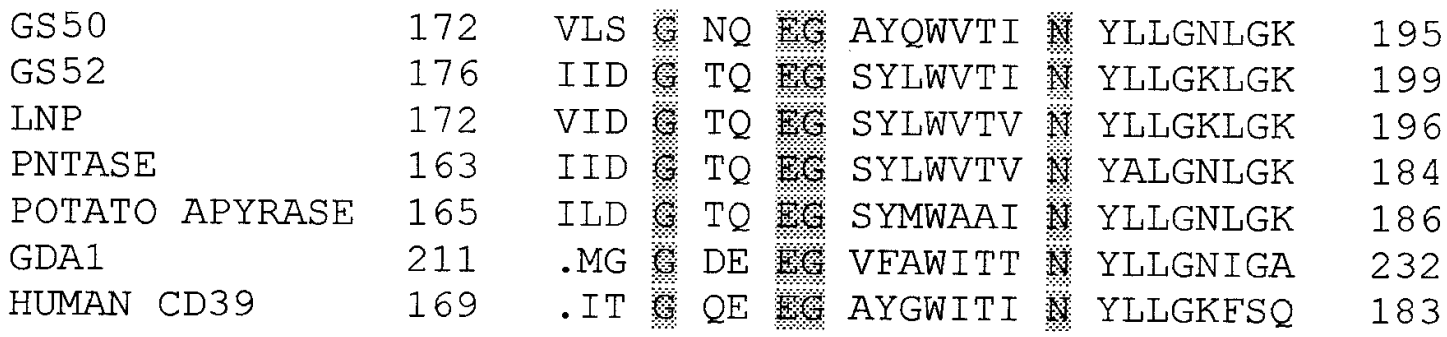

\begin{tabular}{|c|c|c|c|c|c|}
\hline GS50 & 199 & ETVAVV I & 10.1. & MAYAISRN & 224 \\
\hline LNP & 179 & KTVGVI L L & $(1.101)$ & MAYAVSKK & 210 \\
\hline PNTPASE & 190 & KTVGVI 率 L & W. $.4 \%$ & MAYAVSKK & 210 \\
\hline POTATO APYRASE & 192 & KTTATI $\mathrm{L}$ & \% & MAYAISNE & 212 \\
\hline GDA1 & 239 & PTAAVF $2 \mathrm{~L}$ & (x, x, sul & IVEAVSEP & 257 \\
\hline HUMAN CD39 & 207 & ETFGAL 意 L & 9010100 & MAYAVSET & 22 \\
\hline GS52 & 203 & KTVGVV & (6.0.2. & VTEVPQNQ & 22 \\
\hline
\end{tabular}

Fig. 1. Multiple protein sequence alignment of selected apyrase proteins. Highlighted text indicates highly conserved regions. Underlined sequence represents region used to design polymerase chain reaction primers for amplification of $g s 50$ and $g s 52$. Only partial sequences are shown. Sequences: GS50 = AF207687; GS52 = AF207688; LNP = AF139870; PNTPASE = Z32743; potato apyrase $=$ U58597; yeast GDA1 = 6320793; and human CD39 = NM_001249). 

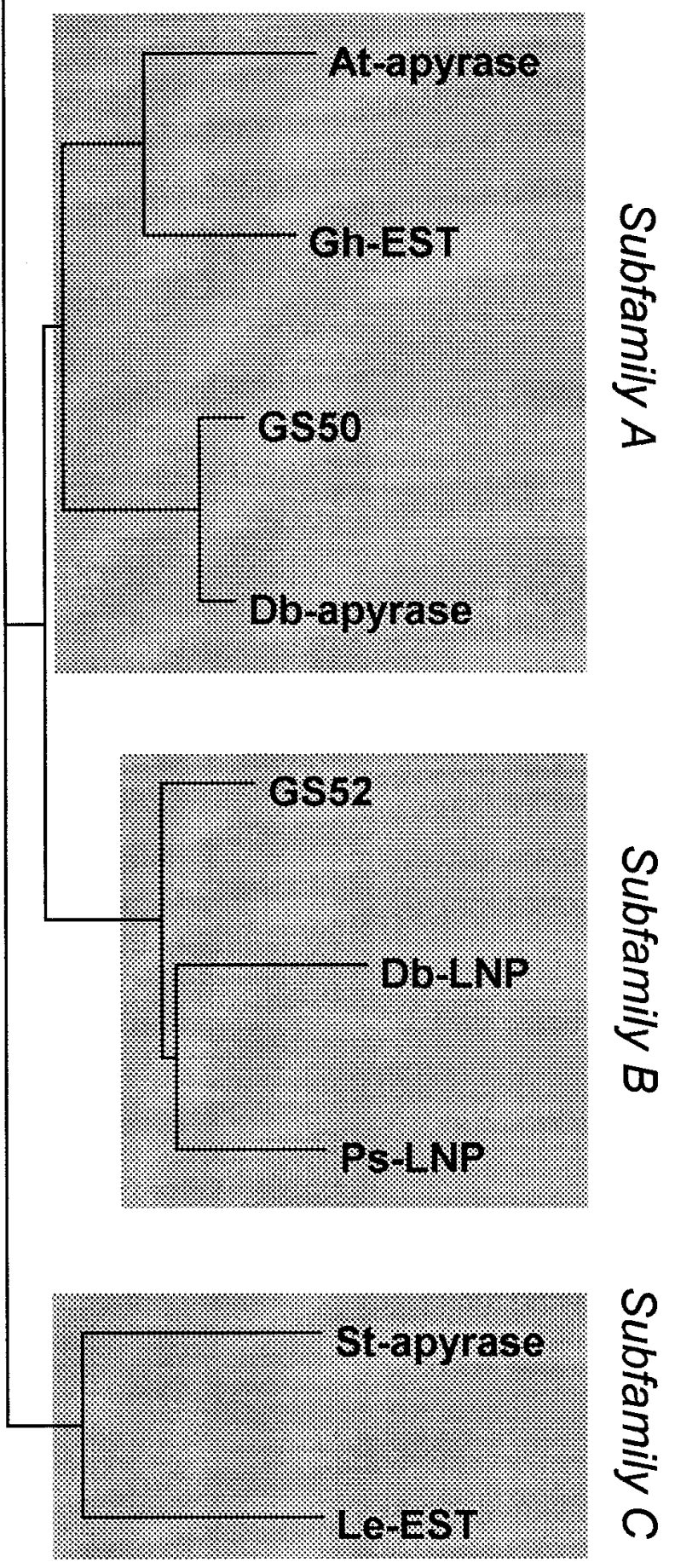

Fig. 2. Neighbor-joining tree of apyrase protein sequences. Three potential subfamilies of plant apyrases are labeled with shaded boxes. Sequences (GenBank accession nos.): Saccharomyces cerevisiae GDA1 (6320793), Arabidopsis thaliana apyrase (AF156783), Gossypium hirsutum expressed sequence tag (EST) BNLGHi13103 (AI729322), GS50, Dolichus biflorus apyrase (AF156781), GS52, D. biflorus LNP (AF139807), Pisum sativum LNP (Z32743), Solanum tuberosum apyrase (U58597), and Lycopersicon esculentum EST cLED13N21 (AI488720). 
fragment of approximately $450 \mathrm{bp}$, reflecting the high degree of nucleotide sequence similarity between gs50 and $g s 52$ within the cDNA coding sequences.

\section{gs50 and $g s 52 \mathrm{mRNA}$ are differentially expressed in soybean tissues.}

The identification and isolation of $g s 50$ and $g s 52$ transcripts was achieved with total RNA from root tissue of $G$. soja. Northern (RNA) blot analysis was initially used to determine tissue and developmental expression, as well the induction of gs50 and gs52 upon rhizobial inoculation (data not shown). However, because of the high degree of sequence similarity between the two cDNAs, a reverse transcription (RT)-PCR approach, with gene-specific primers, was used to differentiate the expression patterns of $g s 50$ and gs52 mRNA. RT-PCR was performed with total RNA isolated from a variety of tissues from $G$. soja. As shown in Figure 3, gs50 and $g s 52$ were expressed in root tissue from soybean. However, their levels of expression, as well as their relative distribution in other tissues, differed significantly. gs52 mRNA was expressed at a higher level than gs50 mRNA in the roots of soybean. Interestingly, both $g s 50$ and gs52 mRNA were highly expressed in flowers, yet neither mRNA was detected in the leaf or in the cotyledon. Conversely, gs50 mRNA expression was maximally localized in the stems of 5-day-old seedlings, whereas gs52 mRNA expression was not detected in the stems. Thus, the differential expression pattern of $g s 50$ and $g s 52 \mathrm{mRNA}$ suggests that these two proteins may function in distinct cellular processes. Interestingly, the mRNA expression pattern of $g s 52$ in the developing roots and flowers of soybean coincided with that of the previously described LNP from $D$. biflorus (Etzler et al. 1999).

gs52 mRNA is induced in the presence of $B$. japonicum.

To determine whether gs50 and/or gs52 mRNA levels were significantly enhanced upon inoculation with $B$. japonicum, RT-PCR was performed with total RNA from root tissue corresponding to the zone of the developing root that is most susceptible to rhizobial infection (i.e., the zone surrounding the first emergent root hairs) (Bhuvaneswari et al.
1981). As shown in Figure 4A (-USDA110), the developmental expression pattern of $g s 50$ reached maximal expression at 3 days, and, by 9 days postimbibition, expression of gs50 had significantly decreased. After inoculation of 3-dayold roots of $G$. soja with $10^{6}$ cells of $B$. japonicum USDA110 (+USDA110) (Fig. 4A), mRNA expression was unchanged, compared with control roots mock inoculated with water. Quantification of these blots is shown in Figure 4B. The developmental expression of gs52 mRNA was similar to that of gs50 (Fig. 5A and B). However, when roots were inoculated with B. japonicum 3 days postimbibition, there was a marked increase in $g s 52$ mRNA levels within 6 $\mathrm{h}$ postinoculation (Fig. 5A and B). The levels of gs52 mRNA remained high until approximately $96 \mathrm{~h}$ postinoculation, when they returned to basal levels. These data clearly identify gs52 as an early nodulin gene.

\section{Production and purification of GS50 and GS52 fusion proteins.}

To generate large amounts of protein for antibody production, the tac-inducible expression vector pGEX-4T-3 was chosen for Escherichia coli expression of GS50 and GS52. The full-length $g_{s} 50$ and $g s 52$ cDNAs were cloned into the expression vector pGEX-4T-3 to generate pGEX50 and pGEX52, respectively. This cloning resulted in translational fusion of $g s 50$ and $g s 52$ to the glutathione Stransferase (GST) gene. Cell extracts of E. coli harboring pGEX50 or pGEX52 were analyzed by sodium dodecyl sulfate-polyacrylamide gel electrophoresis (SDS-PAGE). As shown in Figure 6A, dominant bands of 76 and $78 \mathrm{kDa}$ were observed in the lanes corresponding to the induced fractions (Fig. 6A, lanes marked I). These polypeptides had molecular masses consistent with that predicted for the GST-GS50 (e.g., GST $=26 \mathrm{kDa}, \mathrm{GS} 50=50 \mathrm{kDa}$ ) and GST-GS52 (e.g., GST $=26 \mathrm{kDa}$, GS52 = $52 \mathrm{kDa}$ ) fusion proteins. In the absence of IPTG inducer, no fusion protein was detected (Fig. 6A, lanes marked U). Immunoblot analysis with anti-GST antibodies confirmed SDS-PAGE results (data not shown). The majority of the GS50 fusion protein was present in insoluble inclusion bodies. Therefore, the protein was solubilized with urea, dialyzed, and
A

Root Hypoc. Cotyl. Stem Leaf Flower
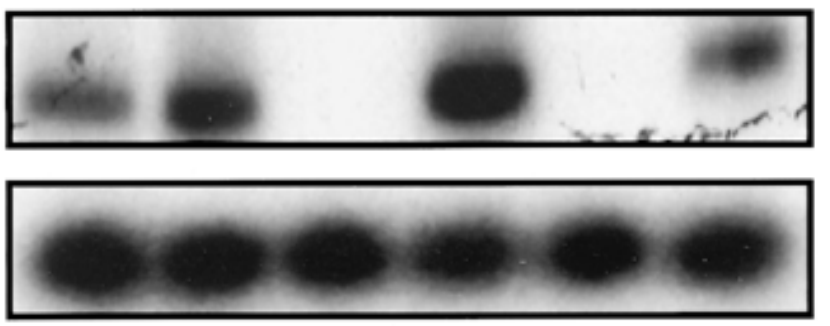

B

\section{Root Hypoc. Cotyl. Stem Leaf Flower}
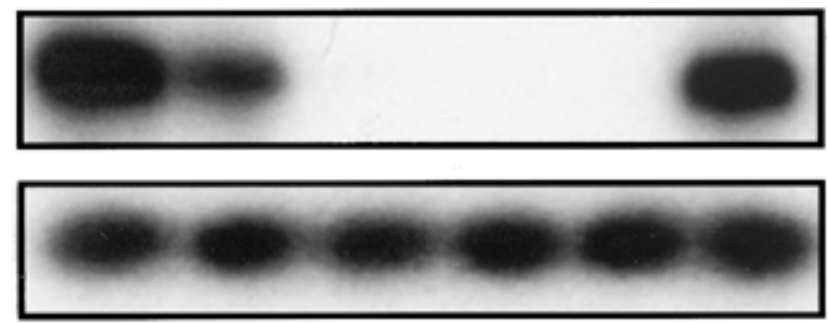

Fig. 3. Reverse transcription-polymerase chain reaction (RT-PCR) analysis of gs50 and gs52 mRNA levels in various tissues from Glycine soja. A, gs50. B, gs52. Root, root tissue from plants 5 days postimbibition (dpi); hypoc., hypocotyls tissue from plants 5 dpi; cotyl., cotyledon tissue from plants $5 \mathrm{dpi}$; stem, stem tissue from plants $5 \mathrm{dpi}$; leaf, leaf tissue from plants 5 to $7 \mathrm{dpi}$; and flower, flower tissue from plants 12 weeks postimbibition. 
affinity purified on a GST-Sepharose 4B column. The GS52 fusion protein was purified in a similar manner. Figure $6 \mathrm{~B}$ and $\mathrm{C}$ show the presence of a single band corresponding to the 76- and 78-kDa GS50 and GS52 fusion proteins, re- spectively, following purification of the proteins on GSTSepharose 4B. Immunoblot analysis with anti-GST antibodies to the eluted proteins confirmed both the presence and purity of the eluate. The purified fusion proteins were

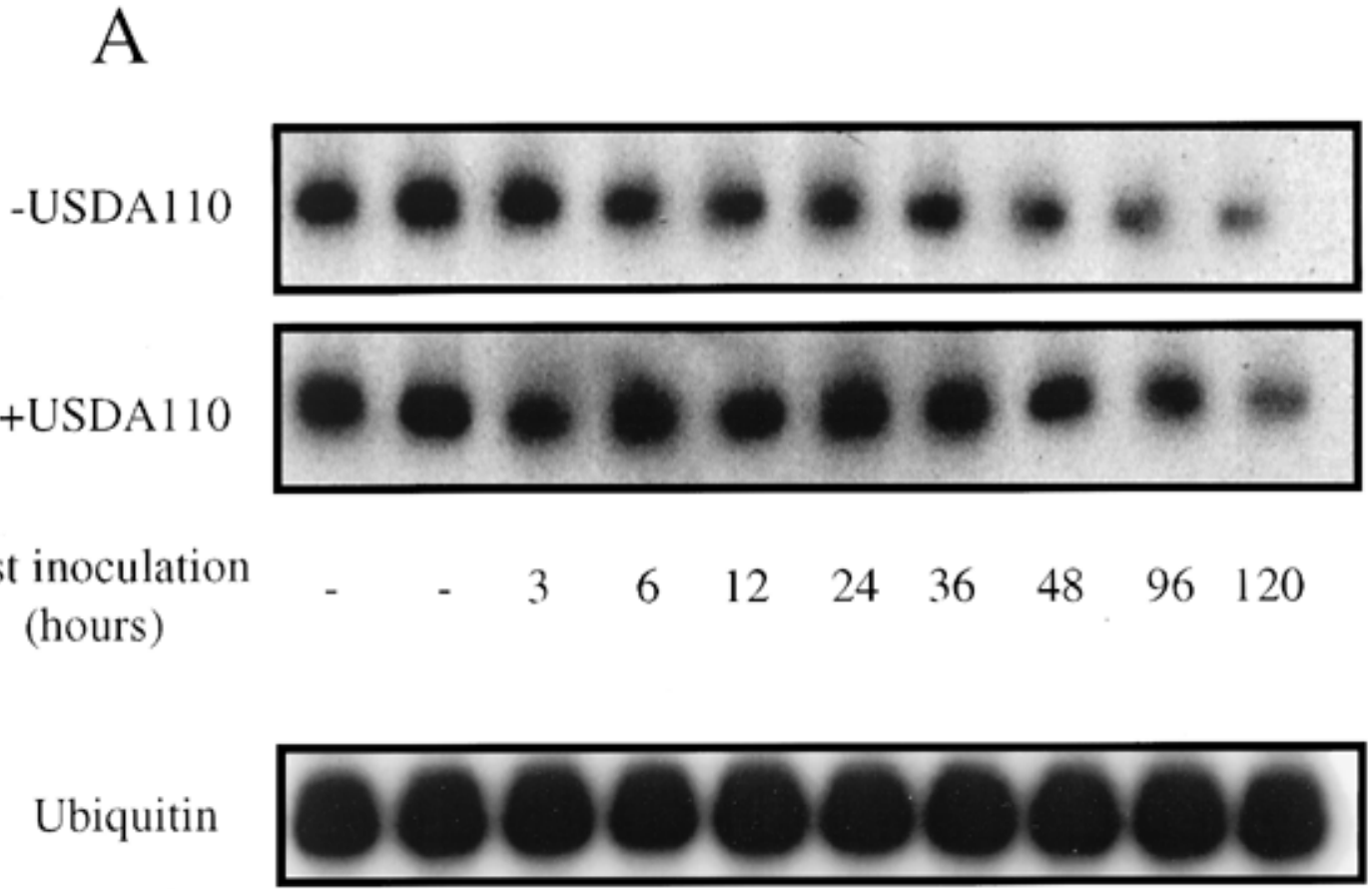

\section{$\begin{array}{ccccccccccc}\begin{array}{c}\text { Post inoculation } \\ \text { (hours) }\end{array} & - & - & 3 & 6 & 12 & 24 & 36 & 48 & 96 & 120\end{array}$}

\section{Ubiquitin}

$\mathrm{B}$

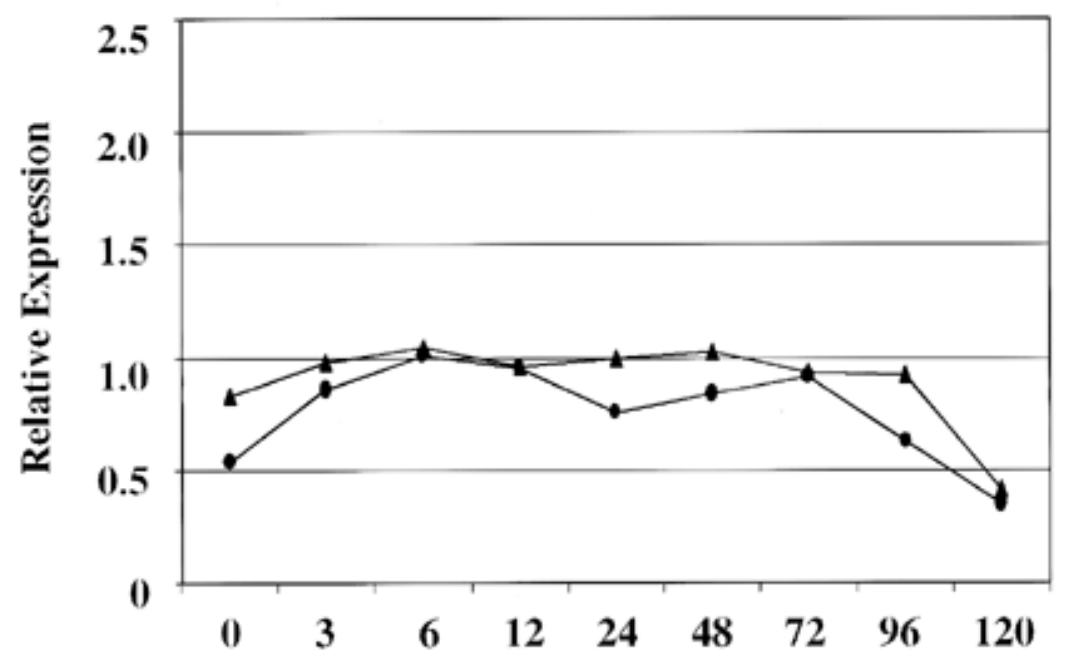

\section{Hours post-inoculation}

Fig. 4. A, Reverse transcription-polymerase chain reaction (RT-PCR) analysis of gs50 mRNA levels in Glycine soja roots uninoculated (-USDA110) or inoculated (+USDA110) with Bradyrhizobium japonicum USDA110. First time point (left): roots from seedlings 2 days postimbibition. With the +USDA110 treatment, roots were inoculated at 3 days postimbibition (second time point from left). After this time, roots were harvested as shown (i.e., hours postinoculation). To control for loading and PCR conditions, an internal control (ubiquitin) was included and is shown at the bottom. B, Graphical representation of relative expression of $g s 50$ as shown in Figure 6A. Relative expression calculated as follows: relative expression $=$ total counts $( \pm$ USDA110)/ total counts ubiquitin control. Relative expression of $g s 50$ in uninoculated roots (-USDA110; $\bullet$ ) and inoculated roots (+USDA110; $\mathbf{\Delta})$. 
used to immunize rabbits for the generation of anti-GS50 and anti-GS52 antibodies. After affinity purification, these antibodies were shown to specifically recognize only their cognate protein (data not shown).

\section{GS50 and GS52 proteins are differentially expressed} in soybean tissues.

The mRNA expression analysis described above suggested that GS50 and GS52 have distinct patterns of tissue localiza-

A

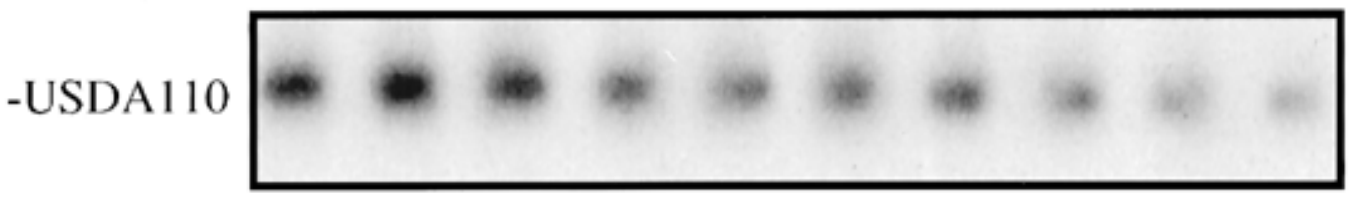

+USDA1 10

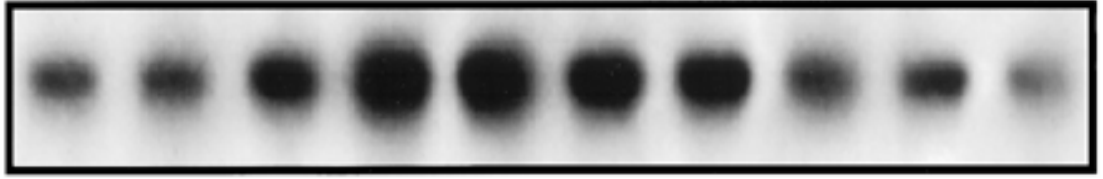

Post inoculation (hours)
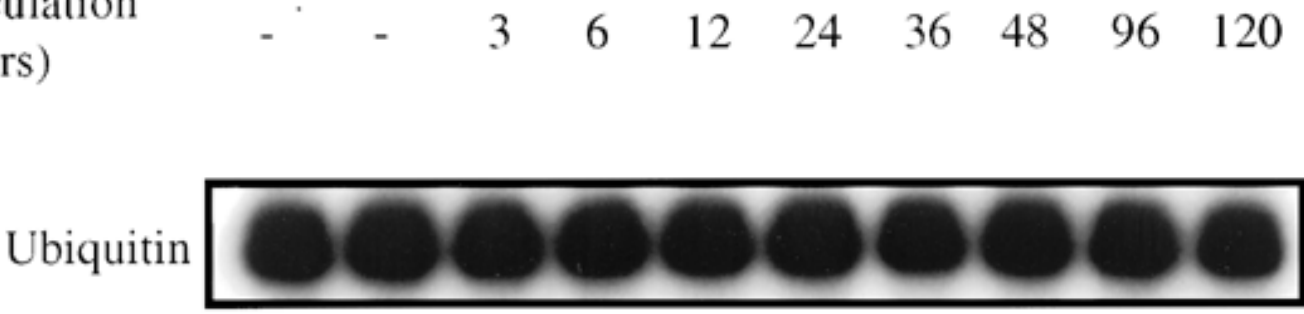

B

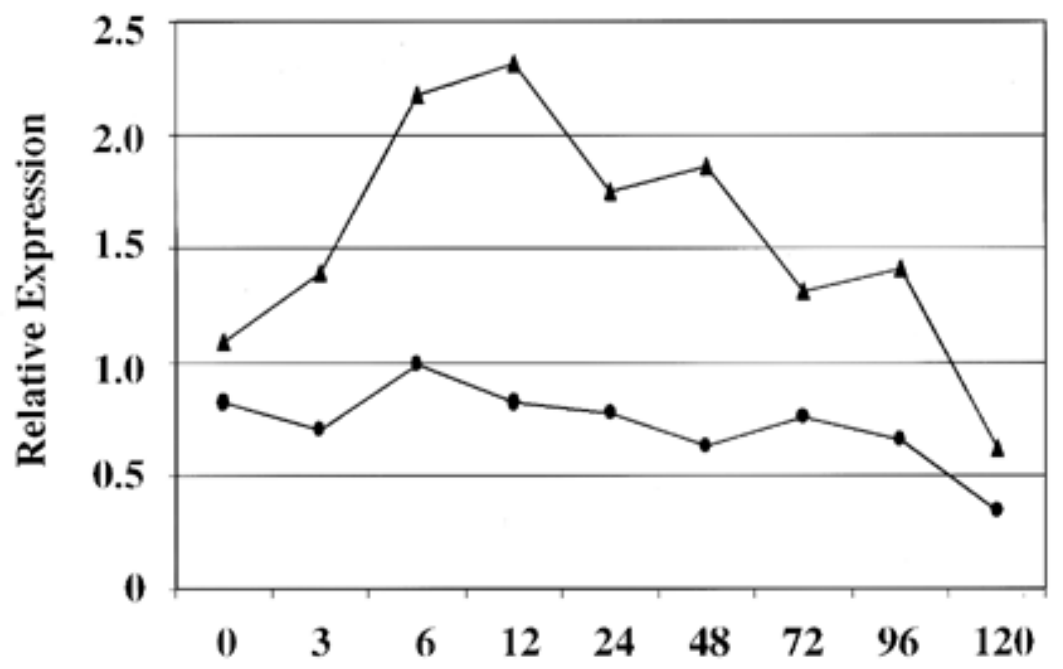

Hours post-inoculation

Fig. 5. A, Reverse transcription-polymerase chain reaction (RT-PCR) analysis of gs52 mRNA levels in Glycine soja roots uninoculated (-USDA110) or inoculated (+USDA110) with Bradyrhizobium japonicum USDA110. First time point (left): roots from seedlings 2 days postimbibition. With the +USDA110 treatment, roots were inoculated at 3 days postimbibition (second time point from left). After this time, roots were harvested as shown (i.e., hours postinoculation). To control for loading and PCR conditions, an internal control (ubiquitin) was included and is shown at the bottom. B, Graphical representation of relative expression of $g s 52$ as shown in Figure 7A. Relative expression calculated as follows: relative expression $=$ total counts $( \pm$ USDA110)/ total counts ubiquitin control. Relative expression of $g s 52$ in uninoculated roots (-USDA110; $\bullet$ ) and inoculated roots (+USDA110; $\mathbf{A})$. 
tion in G. soja. To determine whether the RT-PCR data was representative of the protein localization of these two apyrases, total protein extracts were prepared from various tissues of $G$. soja and were used in Western blot analysis to determine protein localization. As shown in Figure 7B, the tissue localization of GS50 was identical to the RT-PCR data described above (Fig. 3). Maximal expression of GS50 was detected in 5-day-old stem tissue from G. soja, with minimal expression of GS50 localized in 5-day-old roots. Again, similar to the RTPCR data, GS50 was also expressed at a relatively high level in the flowers of $G$. soja.

Western blot analysis of GS52 expression revealed that the epitope was abundant in roots and flowers, similar to the transcript abundance detected with RT-PCR (Fig. 7C). GS52 signal was most abundant in the developing roots of soybean. However, in contrast to the RT-PCR results, GS52 was also detected in the cotyledon and stem at significant levels. The failure of RT-PCR to detect gs52 in the cotyledon suggests that the gs52 mRNA is rapidly turned over in this tissue, thereby limiting the ability of PCR to detect the mRNA. However, although anti-GS52 antibody did not cross-react with GS50, we cannot rule out the presence of a cross-reacting GS52 paralogue in the cotyledon and stem. Perhaps the most interesting result was the detection of a smaller protein (approximately $50 \mathrm{kDa}$ ) (Fig. 7C) in nodule extracts. Considering the specificity of the antibodies used, we favor the hypothesis that this protein may be a posttransitionally modified form of GS52 that is specific to nodule tissues. This idea is supported by the absence of this band in the other samples (e.g., root, stem, and flower) (Fig. 7C), further excluding the possibility that antibodies to GS52 cross-react with GS50. However, we cannot rigorously exclude the possibility that the anti-GS52 antibodies are detecting a nodule-specific GS52 paralogue.

\section{Anti-GS52 antibodies block nodulation of soybean by $B$. japonicum USDA110.}

Etzler et al. (1999) demonstrated the ability of anti-LNP antiserum to block nodulation of $D$. biflorus by $B$. japonicum $24 \mathrm{~A} 10$, thereby suggesting a critical role for LNP in the nodulation process of $D$. biflorus. To determine whether antiGS50 and anti-GS52 serum affected the ability of G. soja to be nodulated by its rhizobial symbiont, 2-day-old seedlings were incubated for $1 \mathrm{~h}$ in the presence of antiserum against each protein. As controls, plants were either incubated in the presence of preimmune serum or left untreated. As shown in Figure 8, treatment with antisera to GS52 inhibited nodulation by $B$. japonicum. This inhibition occurred only in the region of the root that had been exposed to the antiserum (i.e., the region above the root tip at the time of nodulation $=$ upper zone). Interestingly, antiserum against GS50 had no effect on the ability of $G$. soja to be nodulated by rhizobia. Control plants (no treatment and preimmune) showed normal nodulation phenotypes.

\section{Subcellular localization of GS50 and GS52}

with membrane separation in sucrose density gradients.

Previous studies of plant apyrase proteins suggested that they may be associated with cellular membranes (e.g., Chen

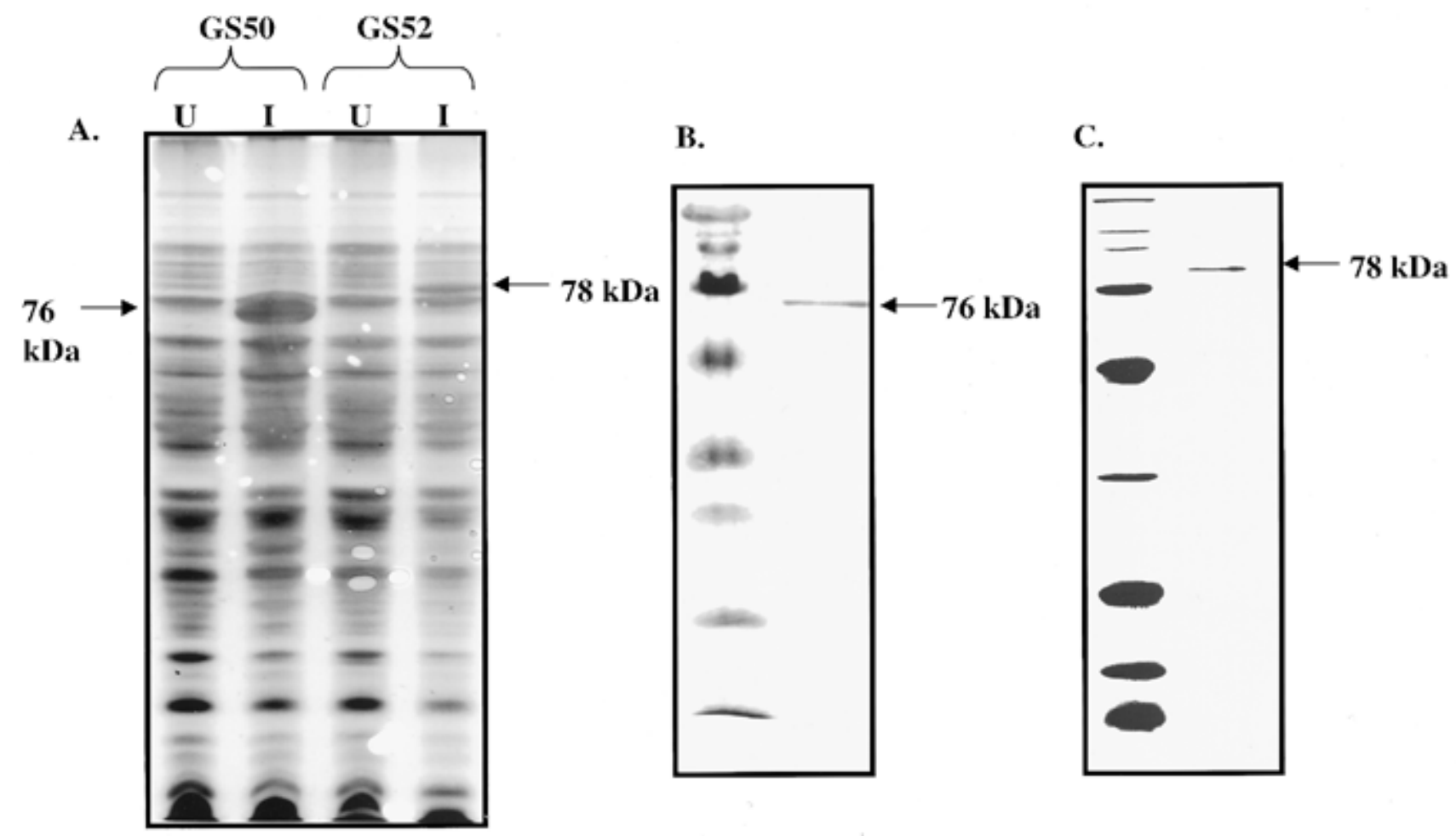

Fig. 6. A, Silver-stained sodium dodecyl sulfate-polyacrylamide gel electrophoresis (SDS-PAGE) analysis of GS50 (left) and GS52 (right) gl utathione Stransferase (GST)-fusion proteins expressed in Escherichia coli. Log phase cultures of E. coli were induced with $500 \mu \mathrm{M}$ IPTG for 1 h. Total protein was separated on a 12\% SDS-PAGE gel. U = Uninduced culture; I = induced culture. B and C, Purified (A) GS50 and (B) GS52 GST-fusion proteins. Molecular masses of the proteins reflect the apyrase protein plus the 26-kDa GST fusion tag. In both cases, protein molecular mass markers are shown on the left; only relevant molecular masses are shown. 
and Roux 1986; Abeijon et al. 1993; Hseih et al. 1996; Etzler et al. 1999). Indeed, hydropathy analysis suggested that GS50 and GS52 possess an N-terminal, membrane-spanning domain. The membrane localization of GS50 and GS52 was examined after separating soybean root membranes by ultracentrifugation on linear 20 to $45 \%$ (wt/wt) sucrose density gradients. The distribution of three membrane marker enzymes/proteins separated by sucrose gradients is shown in Figure 9. The location of the marker proteins coincided with sucrose density gradients previously published for these plant membrane markers (cf. Leonard and Vanderwoude 1976; Giannini et al. 1991). The relative distribution of GS50 and GS52 after centrifugation of soybean root cell homogenate is shown in Figure 10A. Interestingly, GS50 and GS52 appeared to differ in their subcellular localization. This is shown most clearly in Figure10B, where densitometry scans of Figure 10A are directly compared with the peak fractions of the marker proteins identified in Figure 9. As shown, GS50 localized to membrane fractions corresponding to the Golgi membrane marker activity (latent UDPase; i.e., UDPase activity peaked at fraction 10, while maximum GS50 localization peaked in fraction 9). Conversely, GS52 localized to membrane fractions corresponding to the peak of $\mathrm{H}^{+}$-ATPase activity, a marker enzyme for the plant plasma membrane, i.e., ATPase activity peaked in fraction 6 (Fig. 9), as did GS52 Western localization (Fig. 10).

\section{Genetic mapping of gs52 on an integrated genetic linkage map of the soybean genome.}

The availability of genetic maps consisting of polymorphic, DNA marker loci provides a basis for identifying protein function by association with genetic loci of known phenotype. In an effort to determine whether either $g s 50$ or gs52 map to regions of known protein function (e.g., known symbiotic genes) within the soybean genome, or whether restriction fragment length polymorphism (RFLP)-based mapping might identify other apyrase homologues, full-length cDNAs encoding GS50 and GS52 were mapped in a recombinant inbred population of $90 \mathrm{~F}_{5: 6}$ individuals derived from a cross between Evans and PI 209332. Southern blot analysis showed that gs52 was polymorphic within the mapping population, but failed to detect a polymorphism with $g s 50$ as a probe (data not shown). Based on multipoint and two-way contingency table analysis, gs52 mapped $18 \mathrm{cM}$ below (centromeric) marker Satt249 and 10 cM below marker A060_1. Interestingly, gs52 mapped to molecular linkage group (MLG) J, which carries a restricted nodulation gene $R j 2$, resistance genes Rps2 and Rmd (Polzin et al. 1995), a quantitative resistance locus for cyst nematode (Concibido et al. 1996), and numerous resistance gene analogs (Kanazin et al. 1996). Although only a few centimorgans away from one resistance gene analog locus, gs52 was several centimorgans away from the other loci.

\section{DISCUSSION}

Relative to animals, few plant receptor proteins have been identified. Identification of a bonafide Nod signal receptor protein would be a major advance and lead to further exploration of the associated cellular signaling mechanism leading to nodule organogenesis. Therefore, considerable excitement was generated by the recent report of a unique lectin (DB46), isolated from the roots of the legume $D$. biflorus, with the ability to specifically bind the lipo-chitin Nod signals produced by a
A)

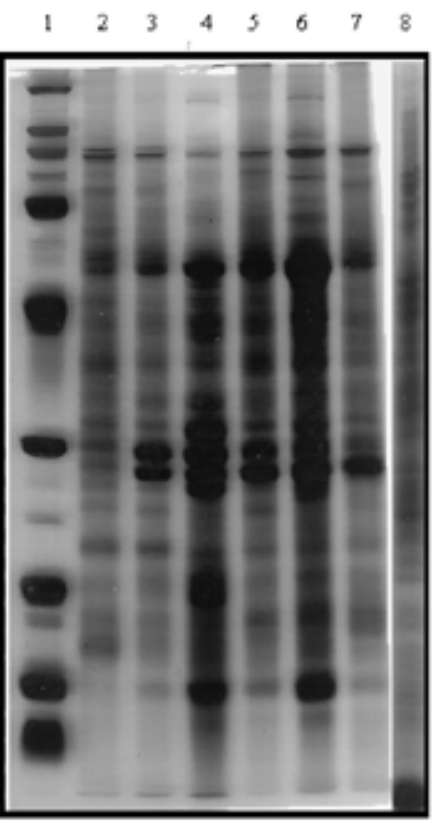

B)

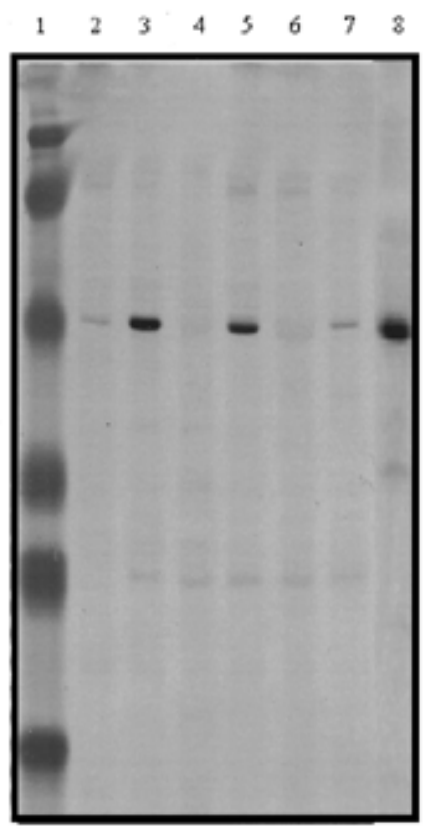

C)

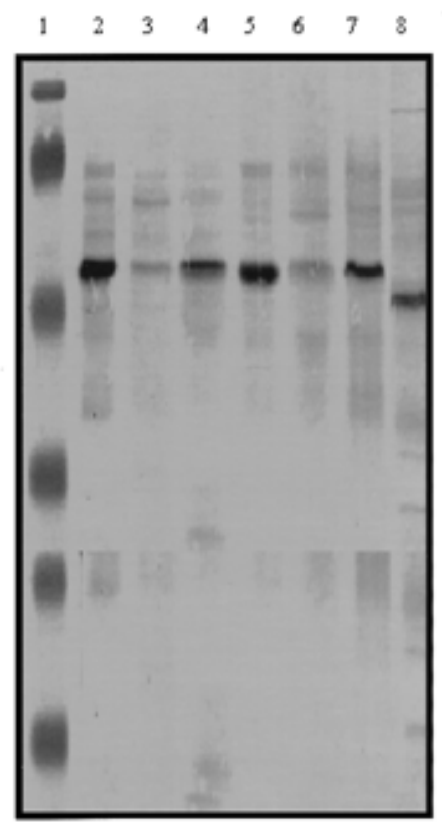

Fig. 7. Western blot (immunoblot) analysis of total protein extracts from various tissues and nodules from Glycine soja. A, Sodium dodecyl sulfatepolyacrylamide gel electrophoresis (SDS-PAGE) silver-stained gel of total protein extracts. B, Western blot with antigen-purified anti-GS50 IgG antibody. C, Western blot with antigen-purified anti-GS52 IgG antibody. Lane 1, Broad range molecular weight markers (different markers used in C); lane 2 , roots ( 5 days postimbibition); lane 3 , hypocotyls ( 5 days postimbibition); lane 4 , cotyledon ( 5 days postimbibition); lane 5 , stem ( 5 days postimbibition); lane 6, leaf (5 to 7 days postimbibition); lane 7, flower (12 weeks postimbibition); and lane 8, nodule (15 days postinoculation). 
variety of rhizobia (Etzler et al. 1999). Historically, legume lectins have been of interest for their proposed role in nodulation; yet, to date, a precise role for these proteins has not been defined. Interestingly, DB46 was found to bind Nod signals from a variety of rhizobia, and showed the highest affinity for the Nod signal produced by B. japonicum and Rhizobium sp. strain NGR234, both of which can nodulate D. biflorus. In an effort to define the possible role of apyrases in soybean nodulation, we sought to isolate a putative orthologue to LNP from soybean $(G$. soja) roots. $G$. soja was chosen since this plant had been shown to respond well to Nod signal addition in previous experiments (e.g., Sanjuan et al. 1992; Stacey et al. 1994). PCR amplification with primers to conserved motifs found in all apyrase proteins identified two apyrases, GS50 and GS52, both of which share a degree of sequence similarity to LNP.

It is clear from the phylogenetic analysis of the GS50 and GS52 sequences that GS52 is orthologous to LNP and paralogous to other apyrases, including GS50. Based on the orthology to LNP, we would predict that GS52 would fulfill a very similar biological function for the plant, while GS50 should be similar to LNP only in basic biochemistry. Our other results support this prediction. Despite searching an updated version of dbEST, we were also unable to locate any nonlegume orthologues of LNP, further supporting the hypothesis of Roberts et al. (1999) that LNPs are unique to legumes.
Roberts et al. (1999) also proposed that the potato apyrase is either a primitive or specialized plant apyrase. Our analysis shows these suggestions to be unlikely. The potato and tomato apyrase sequences appear to form a separate subfamily, suggesting that the potato apyrase is not unique at all and therefore neither primitive nor specialized. The existence of other orthologues of the potato apyrase is supported by our recent isolation of five unique apyrase cDNA clones from Medicago truncatula (J. R. Cohn and G. Stacey, unpublished data).

The identification of two apyrase cDNAs in soybean prompted us to explore the possibility that one or both of these apyrases might be involved in nodulation. GS50 and GS52 mRNA showed different patterns of tissue expression. Due to the high degree of sequence similarity between gs50 and gs52, we opted to use RT-PCR, in lieu of Northern blot analysis, to differentiate the expression patterns of the two mRNAs. RT-PCR results indicated that gs50 mRNA was optimally expressed in the stem of G. soja, with minimal expression in the root. Conversely, gs52 mRNA was optimally expressed in the roots of soybean, with a reduced expression in the hypocotyl. Interestingly, both mRNAs were expressed at relatively high levels in the flowers of G. soja. Roberts et al. (1999) recently reported that LNP was also detected in the flowers of $D$. biflorus.

The tissue localization of $g s 50$ and gs52 mRNA suggests that these proteins likely have different physiological roles in the plant. Due to the possible role of apyrases in nodulation,

\section{No Treatment Pre-Immune anti-GS50 anti-GS52}

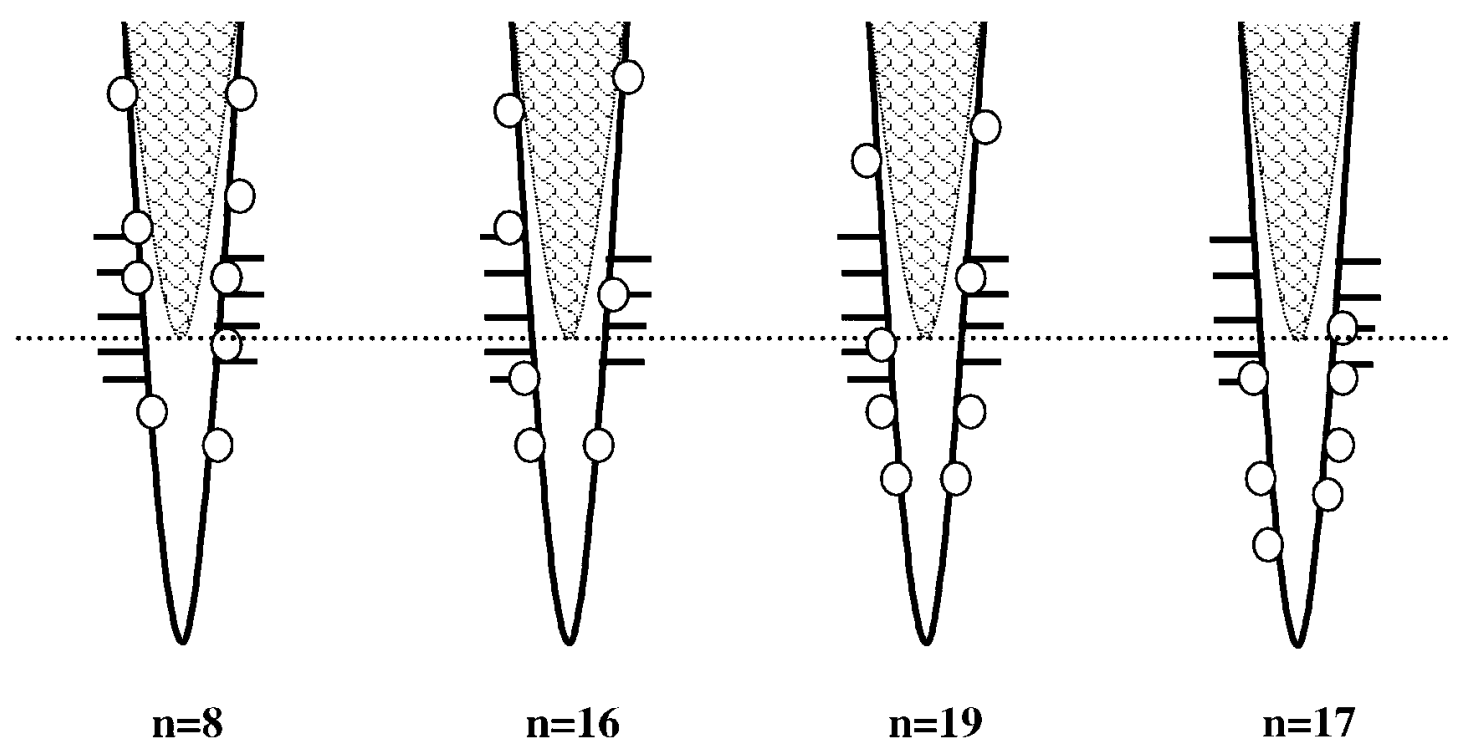

$\begin{array}{llllr}\text { upper zone } & 6 \pm 1 & 4 \pm 1 & 3 \pm 1 & 1 \pm 1 \\ \text { new zone } & 3 \pm 1 & 3 \pm 2 & 5 \pm 3 & 6 \pm 3\end{array}$

Fig. 8. Effect of anti-GS50 and anti-GS52 antiserum on nodulation of Glycine soja by Bradyrhizobium japonicum USDA110. Hatched area represents root at time of antibody treatment and inoculation. Black-bounded, unhatched area represents root at time of analysis (i.e., after root growth). Therefore, upper zone (above dotted line) represents part of the root exposed to antibody and lower zone represents new root growth untreated with antibody. No treatment, control treatment with water; Preimmune, control treatment with preimmune sera; anti-GS50, treated with anti-GS50 antibody; anti-GS52, treated with anti-GS52 antibody. N, number of plants in each treatment; upper zone, number of nodules ( \pm standard error) formed in upper zone of root in each treatment; lower zone, number of nodules ( \pm standard error) formed in lower zone of root in each treatment. Data are from a single experiment. Replicate experiments yielded similar results. 


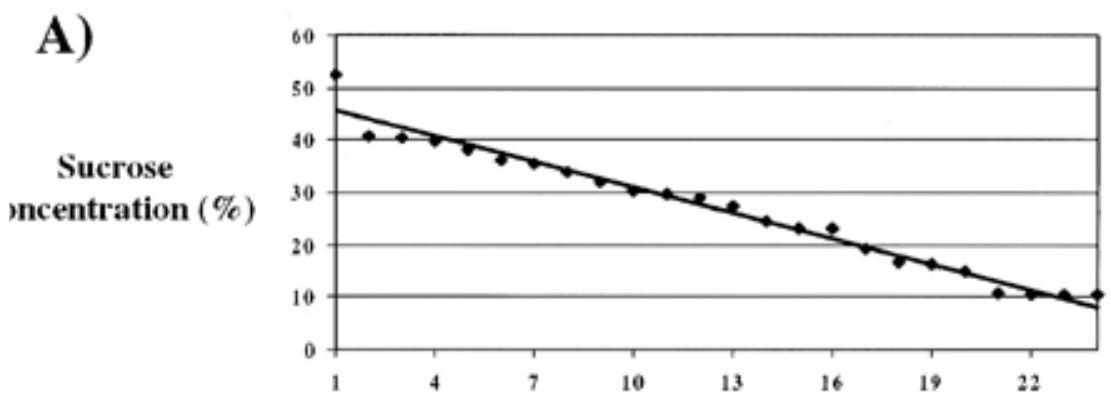

B)

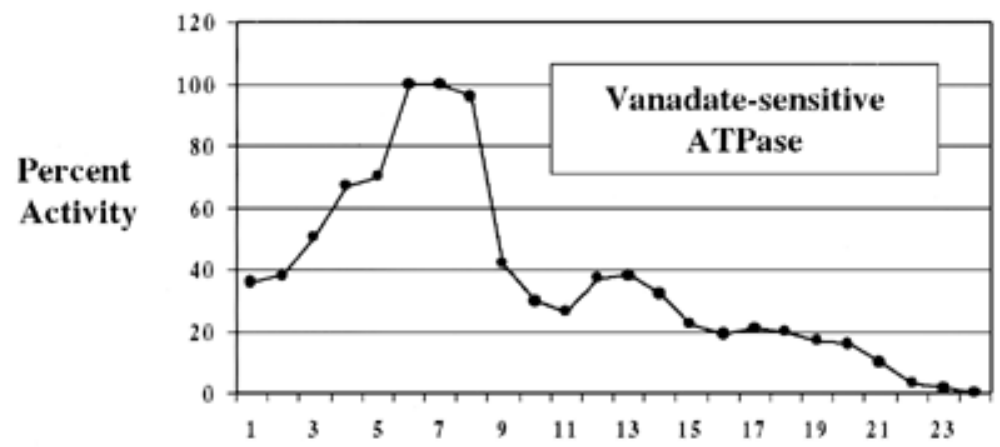

C)

Fraction number

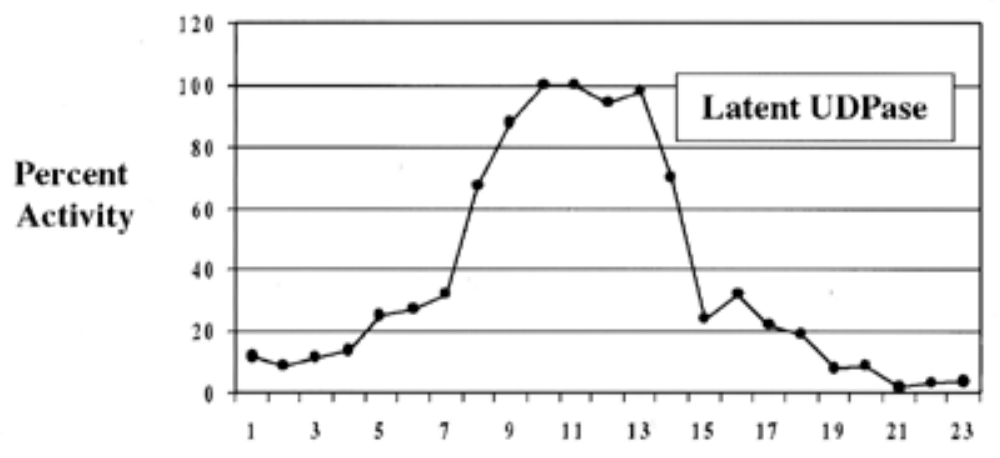

D)

(Fraction number)

$\begin{array}{llllllllllll}8 & 9 & 10 & 11 & 12 & 13 & 14 & 15 & 16 & 17 & 18 & 19\end{array}$

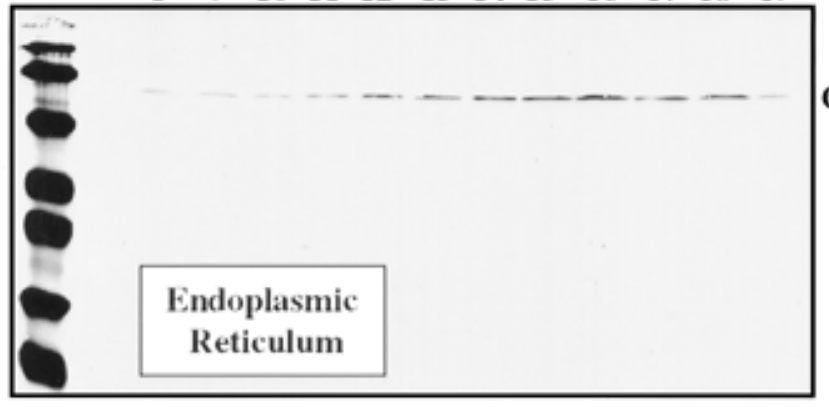

Calnexin

$70 \mathrm{kDa}$

Fig. 9. Localization of marker proteins after sucrose gradient centrifugation. A, Sucrose concentrations of various gradient fractions based on refractive index. B, Plasma membrane marker, vanadate-sensitive ATPase-activity. C, Golgi membrane marker, latent UDPase activity. D, Endoplasmic reticulum (ER) membrane marker, Western blot (immunoblot) of protein in gradient fractions with monoclonal antibodies to oat calnexin (only selected fractions are shown). Numbers above represent gradient fraction number. Molecular weight markers are shown in the left-most lane. 
we specifically focused on the expression of gs50 and gs52 in soybean roots. In uninoculated roots, both $g s 50$ and gs $52 \mathrm{mRNA}$ accumulated to maximal levels within 3 days of imbibition. By 9 days postimbibition, expression of both $g s 50$ and gs52 was reduced significantly. Previous reports supported the hypothesis that the differentiating epidermal cells that lie just behind the rapidly growing root tip are the region of the root most susceptible to rhizobial infection (reviewed in Caetano-Anollés and Gresshoff 1991). Thus, the expression of both apyrases appeared to parallel the susceptibility of the developing root to rhizobial infection.
A number of host-responsive genes expressed in the roots of legumes have been extensively characterized for their temporal and spatial expression patterns upon rhizobial inoculation. Among these, the early nodulins are the best characterized. For example, Minami et al. (1996) demonstrated the rapid accumulation (within $48 \mathrm{~h}$ ) of ENOD40 mRNA in response to root inoculation with $B$. japonicum cells or Nod signal. RTPCR analysis was used to determine whether $g_{s} 50$ and/or $g s 52$ mRNA levels increased upon inoculation of soybean roots with B. japonicum. Expression of gs50 was unchanged after

\section{$\begin{array}{lllllllllllll}6 & 7 & 8 & 9 & 10 & 11 & 12 & 13 & 14 & 15 & 16 & 17\end{array}$}
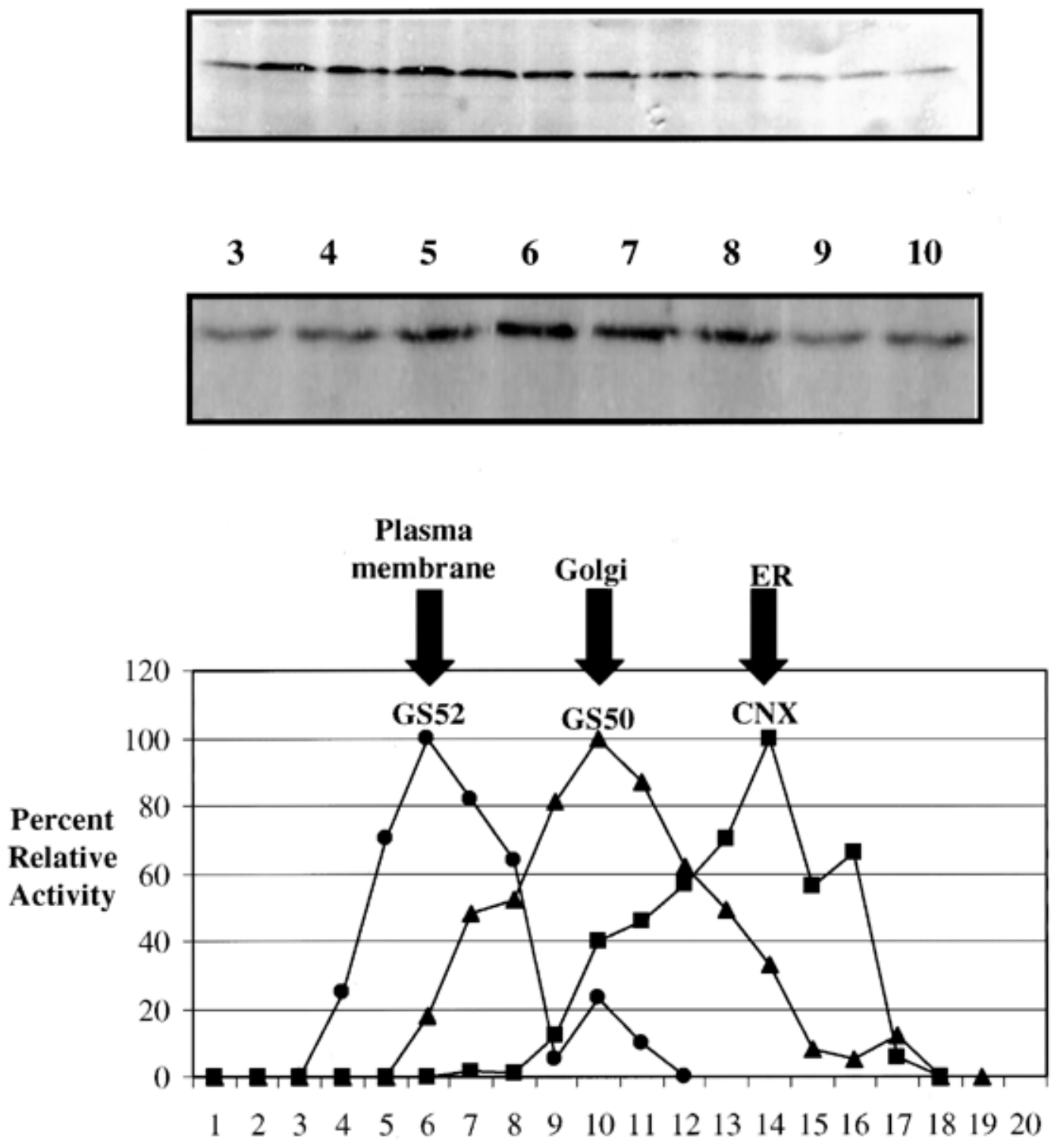

\section{Fraction number}

Fig. 10. Western blot (immunoblot) analysis of sucrose gradient fractions with either antigen-purified anti-GS50 antibody (top) or antigen-purified, antiGS52 antibody (bottom). Numbers above represent gradient fraction number. Only selected fractions are shown. Sucrose gradient localization of GS50 and GS52 relative to membrane marker proteins. Percent relative activity was determined based on densitometry analysis of Western blots of protein in sucrose gradient fractions (e.g., Fig. 9D and A). Peak fractions containing plasma membrane marker (vanadate sensitive ATPase), Golgi membrane marker (latent UDPase), and ER membrane marker (calnexin), as determined in Figure 9, are shown above by arrows. $\mathbf{\square}=$ Densitometry scan of calnexin Western blot (Fig. 9D). $\mathbf{O}=$ Densitometry scan of anti-GS52 Western blot. $\boldsymbol{\Delta}=$ Densitometry scan of anti-GS50 Western blot. 
inoculation of soybean roots. However, gs52 mRNA rapidly accumulated within $3 \mathrm{~h}$ postinoculation, with sustained, enhanced expression detectable beyond $120 \mathrm{~h}$ postinoculation. It may seem surprising, if GS52 is a Nod signal receptor, to see induction of expression in response to rhizobial inoculation. However, the response of GS52 to inoculation is consistent with reports from a number of biological systems showing agonist-induced expression of membrane-localized receptors (e.g., Ng et al. 1997; Perera et al. 1999). Moreover, these data justify classifying $g s 52$ as an early nodulin, and therefore likely involved in the onset of nodulation. Although gs50 mRNA levels were unresponsive to rhizobial inoculation, we cannot exclude the possibility that this protein may also be involved in the nodulation response.

Although the mRNA data indicated that $g s 50$ and $g s 52$ were differentially expressed in soybean tissues, these data did not directly address the protein expression pattern. Therefore, using purified antibodies to both GS50 and GS52, we sought to define the tissue localization of each protein in the various tissues of G. soja. In general, the protein expression patterns of both GS50 and GS52 were similar to the mRNA expression data. However, Western blot analysis clearly showed expression of GS52 in 5-day-old cotyledons from G. soja, while gs52 mRNA was not detected in cotyledons by RT-PCR. One possible explanation for this is that $g s 52$ mRNA may undergo a rapid turnover in these tissues, and RT-PCR failed to detect a signal. A second possibility is that anti-GS52 antibodies are cross-reacting with an additional apyrase paralogue present in the cotyledon of soybean.

A second, more striking observation was the reactivity of anti-GS52 antibodies with a protein of a smaller molecular mass (e.g., $50 \mathrm{kDa}$ ) in nodule extracts. We previously determined that anti-GS50 antibody did not cross-react with GS52 and, likewise, anti-GS52 antibody did not recognize GS50. Therefore, we can exclude the possibility that anti-GS52 antibodies are detecting GS50 in nodule extracts. One possibility is that the signal detected in nodules is in fact GS52, and the protein is posttransitionally modified (e.g., cleaved signal sequence) in nodule tissues. Potato apyrase exists in both soluble and insoluble states that differ in their catalytic properties, isoelectric points, and molecular weights (Handa and Guidotti 1996). Similarly, reports suggest that both the pea apyrase and LNP exist in both an insoluble and soluble state (Chen and Roux 1986; Etzler et al. 1999). However, we only detected this smaller protein in nodule extracts. Therefore, if cleavage of the GS52 signal sequence is producing this small, crossreacting band, it appears specific to nodule development. The physiological consequence of such an event is still unknown. An alternative hypothesis for the appearance of this smaller protein in nodule extracts is that the anti-GS52 antibody is cross-reacting with an unidentified paralogue to GS50 and GS52. However, we do not favor this hypothesis since the antibody to GS52 is highly specific and does not recognize GS50. However, we cannot rule out this possibility since evidence suggests that multiple (e.g., = 5) apyrase proteins are present in Medicago truncatula (J. R. Cohn and G. Stacey, unpublished data).

The ability of antiserum to LNP to block nodulation of $D$. biflorus by Bradyrhizobium spp. (Etzler et al. 1999) prompted us to test the ability of both anti-GS50 and anti-GS52 to block nodulation of soybean. Interestingly, antiserum to GS50 had no effect on the nodulation of soybean by B. japonicum. However, pretreatment of 2-day-old soybean roots with anti-GS52 serum showed a marked decrease in the formation of nodules. Control plants (e.g., no treatment or preimmune sera) showed normal nodulation phenotypes. The inhibition in nodulation by pretreatment of the roots with anti-GS52 serum suggests that GS52 plays an important role in soybean nodulation.

The subcellular localization of apyrases is largely undefined. Two yeast orthologues, GDA1 and YND1, have been identified as Golgi-localized apyrases (Abeijon et al. 1993; Gao et al. 1999). The Nod signal-binding protein, LNP, has been localized to the surface of root hairs in D. biflorus by immunofluorescence. However, it remains to be determined whether LNP is membrane associated (Etzler et al. 1999). Our data clearly localized GS52 to sucrose gradient fractions enriched in plasma membrane. This localization would be consistent with a role as a membrane-associated receptor for the Nod signal. Based on cellular localization of GS50, we hypothesize that it is likely an endo-apyrase that functions in a capacity similar to that of GDA1 or YND1 from S. cerevisiae (Abeijon et al. 1993; Gao et al. 1999).

GS52 appears the more likely candidate of the two soybean apyrases described in the current study to function in nodulation. The tissue localization data suggest that GS52 is localized in the root and, more specifically, within the region of the root known to be susceptible to rhizobial infection. Localization of GS52 to the plasma membrane suggests that it may function as an ecto-apyrase, with its catalytic domain positioned in the extracellular matrix. Induction of GS52 mRNA in response to inoculation with Bradyrhizobium spp. provides perhaps the most compelling evidence that GS52 plays some role in nodulation. This, coupled with the ability of anti-GS52 antibodies to block nodulation, strongly argues for the involvement of GS52 as an essential component of the soybean nodulation response.

Based on the homology of GS50 and GS52 to apyrases from a variety of species, gs50 and gs52 likely do encode active apyrases. However, definitive proof will require demonstration of the appropriate enzymatic activity. Preliminary results with both GS50 and GS52 proteins purified from E. coli failed to show apyrase-like activity (R. B. Day and G. Stacey, unpublished data). It is likely these failures are due to difficulties with purification of the proteins from $E$. coli. It will be critical in the future to conduct a thorough analysis of GS50 and GS52 enzymatic activity and to determine whether or not their activity is modulated by addition of Nod signals (cf. Etzler et al. 1999).

The gs52 gene was mapped to MLG J of the soybean integrated genetic linkage map (Cregan et al. 1999). Recent data have shown that the $M$. truncatula apyrase genes are clustered on the genetic map (J. R. Cohn, D. Cook, and G. Stacey, unpublished data). Therefore, the mapping of gs52 may allow us to identify other, closely linked, apyrase genes. With this in mind, soybean bacterial artificial chromosome clones that hybridize to gs50 and gs52 have been isolated. These clones should be an excellent starting point for characterizing clusters of apyrase genes in soybean, if they exist. Moreover, because of synteny among the genomes of different legume species (Boutin et al. 1995), positioning gs52 on the soybean genome might allow for the identification of apyrase genes in a variety of legume species. An intriguing possibility would be to cor- 
relate the location of the apyrase gene with a mutation that results in a nodulation defect. Large-scale mutagenesis efforts currently underway in M. truncatula and Lotus japonicus may ultimately make this possible.

\section{MATERIALS AND METHODS}

\section{Bacterial culture media and growth conditions.}

All strains of $E$. coli were grown and maintained on LuriaBertani (LB) medium (Sambrook et al. 1989) at $37^{\circ} \mathrm{C}$. B. japonicum USDA110 was grown and maintained on RDY medium (So et al. 1987) at $30^{\circ} \mathrm{C}$. The antibiotics used for plasmid maintenance and selection in $E$. coli were as follows: ampicillin $(200 \mu \mathrm{g} / \mathrm{ml})$, kanamycin $(100 \mu \mathrm{g} / \mathrm{ml})$, and tetracycline $(25 \mu \mathrm{g} / \mathrm{ml})$.

\section{Plant germination and growth conditions.}

G. soja (PI 468397) seeds were surfaced-sterilized in $20 \%$ hypochlorite for $20 \mathrm{~min}$ and then washed six times with sterile, distilled water. Seeds were scarified in concentrated $\mathrm{H}_{2} \mathrm{SO}_{4}$ for $5 \mathrm{~min}$, followed by six washes with sterile, distilled water. Seeds were germinated in petri dishes on sterile Whatman paper at $30^{\circ} \mathrm{C}$ for 2 days in the dark. Following germination, seeds were transferred to sterile plant growth pouches (Mega International, Minneapolis, MN, U.S.A.) and grown in a model CU-32L plant growth chamber (Percival Scientific, Boone, IA, U.S.A.) under a 16-h day/8-h night cycle at $28 / 22^{\circ} \mathrm{C}$ with 70 to $80 \%$ relative humidity.

\section{Isolation of total RNA and reverse transcription.}

Total RNA was isolated from 3- and 5-day-old roots of $G$. soja with Trizol Reagent (Gibco BRL, Gaithersburg, MD, U.S.A.) according to the manufacturer's protocol. RNA quantity and integrity were determined by monitoring absorbance at $A_{260}$ and by agarose gel electrophoresis, respectively. Reverse transcription of total RNA was performed as follows and the following primers were used: $g s 50$ forward full $=5^{\prime}$ GCGTCTAGAGCAACTATGAG-3'; $g s 50$ reverse full $=5^{\prime}$ GCCTCTAGACATATGGCTCCTCG-3'; gs52 forward full = 5'-GCCTCTAGAGCATGGTACTTGTGC-3'; gs52 reverse full $=5^{\prime}$-GCCTCTAGACCCAGCATAAGC-3'). These primers, corresponding to the $5^{\prime}$ and $3^{\prime}$ full-length ends of $g s 50$ ( $g s 50$ forward/reverse full, see above) and gs52 ( $g s 52$ forward/ reverse full, see above) were used in PCRs as follows: $5 \mu \mathrm{l}$ of cDNA + $10 \mathrm{mM}$ Tris-HCL (pH 8.0), $50 \mathrm{mM} \mathrm{KCl,} 2.5 \mathrm{mM}$ $\mathrm{MgCl}_{2}, 5 \mathrm{U}$ Taq DNA Polymerase (Promega, Madison, WI, U.S.A.). DNA primers were added to a final concentration of $2.5 \mu \mathrm{M}$. PCR conditions were as follows: 25 cycles $\left(94^{\circ} \mathrm{C}\right.$ for $1 \mathrm{~min}, 55^{\circ} \mathrm{C}$ for $3 \mathrm{~min}$, and $72^{\circ} \mathrm{C}$ for $1 \mathrm{~min}$ ), with $10 \mathrm{~min}$ of extension time at $72^{\circ} \mathrm{C}$. As an internal control, primers specific for ubiquitin were also included (ubiquitin forward $=5^{\prime}$ GGGTTTTAAGCTCGTTGT-3'; ubiquitin reverse $=5^{\prime}$ GGACACATTGAGTTCAAC-3').

An aliquot $(5 \mu \mathrm{l})$ of total RNA was utilized for TD-PCR (Don et al. 1991) in the presence of $10 \mathrm{mM}$ Tris- $\mathrm{HCl}(\mathrm{pH} \mathrm{8.0)}$, $50 \mathrm{mM} \mathrm{KCl}, 2.5 \mathrm{mM} \mathrm{MgCl}_{2}$, and $1 \mathrm{U}$ Taq DNA polymerase (Promega). PCR cycle conditions were as follows: $94^{\circ} \mathrm{C}, 1$ min; $52^{\circ} \mathrm{C}, 1 \mathrm{~min}$; and $74^{\circ} \mathrm{C}, 3 \mathrm{~min}$. The annealing temperature was decreased $2^{\circ} \mathrm{C}$ every fourth cycle from $55^{\circ} \mathrm{C}$ to a "touchdown" at $37^{\circ} \mathrm{C}$. Degenerate primers designed to a conserved, internal, apyrase motif found in pea (Hseih et al.
1996), potato (Handa and Guidotti 1996), and LNP (Etzler et al. 1999) were used at a $5 \mu \mathrm{M}$ final concentration. Primers were designed specific for $g s 50\left(g s 50\right.$ TD-PCR forward $=5^{\prime}$ ATTGATGGAACCCAAGAAGG-3'; $g s 50$ TD-PCR reverse $=$ 5'-GGYAAAGMTGATATGGCTTC-3'; Y = C/T; $\mathrm{M}=\mathrm{A} / \mathrm{C}$ ) or $g s 52$ ( $g s 52$ TD-PCR forward = 5'-TGGRATWTGGRATGGTGGA-3'; gs52 TD-PCR reverse = AGAGGCCATGCDGYTCCACA-3'; R = A/G; $\mathrm{W}=\mathrm{A} / \mathrm{T} ; \mathrm{D}=\mathrm{A} / \mathrm{G} / \mathrm{T})$. PCR products were separated by electrophoresis in a $0.8 \%(\mathrm{wt} / \mathrm{vol})$ agarose gel, and visualized by staining with ethidium bromide.

\section{TA cloning and DNA sequencing of PCR-amplified products.}

PCR products corresponding to DNA fragments of expected sizes ( $g s 50,850 \mathrm{bp} ; g s 52,351 \mathrm{bp}$ ) were cloned into the TAcloning vector pCR2.1 with the TA Cloning Kit (Invitrogen, Carlsbad, CA, U.S.A.) to give plasmids pDAY15 (gs50) and pDAY9 (gs52). Ligated products were transformed into $I N V \alpha F^{\prime}$ One Shot competent cells (Invitrogen) according to the manufacturer's specifications. Plasmid DNA was isolated according to the method of Sambrook et al. (1989).

All automated DNA sequencing was done at the University of Tennessee Molecular Biology Resource Facility with the ABI Prism Dye Terminator Cycle Sequencing reaction kit on an ABI 373 DNA sequencer (Perkin-Elmer, Foster City, CA, U.S.A.). The initial sequence data text files were edited following comparison with the same data displayed in four-color electropherograms before they were analyzed further. In both cases, both strands of two independent clones were sequenced to ensure the fidelity of the sequences.

\section{Phylogenetic analysis of protein sequences.}

Protein sequences were aligned with CLUSTALW (Thompson et al. 1994) under default parameters. End gaps were trimmed, leaving a 214-amino acid multiple sequence alignment for phylogenetic inference. Translations of EST sequences were generated from TFASTX3 (Pearson et al. 1997) alignments with Db-LNP (AF139807). Bootstrap and neighbor-joining analyses were performed with the SEQBOOT and NEIGHBOR programs of the PHYLIP package (J. Felsenstein, Department of Genetics, University of Washington, Seattle, U.S.A.).

\section{Isolation of full-length cDNAs encoding gs50 and gs52.}

Extension of the cDNA ends of the initial gs50 and gs52 partial clones was achieved with the $5^{\prime}$ and $3^{\prime}$ RACE kit (Gibco BRL), according to the manufacturer's specifications. The following primers were used: $g s 503^{\prime} \mathrm{RACE}=5^{\prime}$ GGTGAGGCAAGTTGAGTATCAA-3'; gs50 5' RACE $=5^{\prime}$ GTAATACCCATCAAAGCCAGCCAA-3'; gs52 3' RACE = 5'-GCCAAGTCCACCTATCCAAACC-3'; gs52 5' RACE = 5'-GCCACTGTAATCTCTTGCC-3'. Cloning, transformation, and DNA sequencing were performed as described above.

After sequence data were obtained from the initial PCR, as well as the $3^{\prime}$ and $5^{\prime}$ RACE products, primers ( $g s 50$ forward/ reverse and $g s 52$ forward/reverse, see above) were designed to regions flanking the coding sequence (ATG start) of both $g s 50$ and $g s 52$. Five microliters of cDNA was used in a PCR, with $5 \mu \mathrm{M}$ concentrations of the full-length primers flanking the coding sequence of $g s 50$ and $g s 52$. PCR conditions were as described above, except 1 U of Pfu DNA polymerase (Stratagene, La Jolla, CA, U.S.A.) was substituted for Taq poly- 
merase. The PCR products corresponding to the full-length cDNAs were cloned (see above) into pCR2.1 to yield pDAY46-A (full-length $g s 50$ ) and pDAY52new (full-length $g s 52$ ).

\section{Southern blot analysis.}

Twenty micrograms of genomic DNA was digested with EcoRI, HindIII, or PstI overnight at $37^{\circ} \mathrm{C}$, according to the supplier's specifications. Digests were loaded onto a $0.8 \%$ agarose gel and separated for $1 \mathrm{~h}$ at $100 \mathrm{~V}$, and blotted onto ZetaProbe Nylon membrane (Bio-Rad Laboratories, Hercules, CA, U.S.A.), according to the method of Sambrook et al. (1989). Hybridization and washing were performed according to the manufacturer's protocol. Gene-specific probes corresponded to the RACE-PCR products. For $g s 50$, this region corresponded to the $5^{\prime}$ region from nucleotides -4 to 410 . For gs52, this region corresponded to the $3^{\prime}$ region from nucleotides 1,067 to 1,462 . These gene-specific probes were labeled to a specific activity of $10^{8} \mathrm{cpm}$ of DNA per $\mu \mathrm{g}$ with random primer labeling (Promega).

\section{Northern blot analysis.}

Total RNA was separated on formaldehyde denaturing gels in $1 \%$ agarose and blotted onto ZetaProbe Nylon membrane (Bio-Rad) according to the method of Sambrook et al. (1989). Hybridization and washing was performed as described for the Southern blots. In all cases, gene-specific probes were labeled to a specific activity of $10^{8} \mathrm{cpm}$ of DNA per $\mu \mathrm{g}$ with random primer labeling (Promega).

\section{Developmental expression of gs50 and gs52 mRNA.}

Root tissue was harvested at time points ranging from 2 days to 9 days postimbibition of $G$. soja seeds. In all $g s 50$ and gs52 expression-analysis experiments, the zone of the first emergent root hairs on each plant was marked when plants were transferred to growth pouches. To standardize the localization of mRNA expression, segments of the roots corresponding to $1 \mathrm{~cm}$ above and $1 \mathrm{~cm}$ below this mark were used in all expression studies. Total RNA was isolated and reverse transcribed as described above.

To examine the tissue-specific expression of $g s 50$ and $g s 52$ mRNA, total RNA was isolated from roots, hypocotyls, cotyledons, stems, leaves, flowers, and nodules with Trizol Reagent (Gibco BRL). Total RNA was reverse-transcribed and processed as described above. As an internal control, primers specific for ubiquitin were also included (ubiquitin forward/ reverse, see above). After RT-PCR, PCR products were separated on a $1.0 \%$ agarose gel and blotted onto Zeta Probe nylon membrane (Bio-Rad) according to the manufacturer's specifications. Membranes were hybridized to full-length $g s 50$ or gs52 cDNA probes that were ${ }^{32} \mathrm{P}$-labeled with a random primer labeling kit (Promega).

To examine the expression of $g_{s} 50$ and $g s 52 \mathrm{mRNA}$ in response to inoculation with $B$. japonicum, plants were grown in plastic growth pouches for 2 days, and then inoculated with $10^{6}$ cells of $B$. japonicum USDA110 resuspended in halfstrength plant nutrient solution (PNS) (Wacek and Brill 1976). At various time points (3 to $120 \mathrm{~h}$ postinoculation), root tissue was excised into liquid nitrogen and frozen at $-80^{\circ} \mathrm{C}$ until further use. Total RNA was isolated and reverse transcribed as described above. PCRs were performed exactly as described above. As an internal control, primers specific for ubiquitin were also included (ubiquitin forward/reverse, see above). Bands were visualized after hybridization as described above.

Quantification of radioactive blots was performed with an Instant Imager Electronic Autoradiograph (Packard Instrument Company, Meriden, CT, U.S.A.).

\section{Generation of antibodies to GS50 and GS52.}

GS50 and GS52 were expressed in E. coli cells from the IPTG-inducible tac promoter of the expression vector pGEX4T-3 (Amersham Pharmacia Biotech, Piscataway, NJ, U.S.A.). This plasmid allows for the expression of proteins as a fusion with GST. The in-frame ligation of $g s 50$ and $g s 52$ in pGEX4T-3 (yielding plasmid pGEX50 and pGEX52, respectively) was confirmed by automated DNA sequencing with the pGEX forward primer (Pharmacia Biotech, Uppsala, Sweden).

E. coli strains GEX50 (pGEX50) and GEX52 (pGEX52) were grown overnight with shaking (200 rpm; G25R; New Brunswick Scientific, Edison, NJ, U.S.A.) in $50 \mathrm{ml}$ of LB containing $200 \mu \mathrm{g}$ of ampicillin per $\mathrm{ml}$ at $37^{\circ} \mathrm{C}$. This culture was then diluted into 8 liters of LB containing the same concentration of ampicillin and incubated under the same conditions. When an $A_{600}$ of 0.4 was reached, IPTG (Sigma, St. Louis, MO, U.S.A.) was added to the cultures to a final concentration of $0.25 \mathrm{mM}$, and the cultures were induced for $2 \mathrm{~h}$. After induction, cells were centrifuged at 5,000 rpm (JA-14 rotor; Beckman Instruments, Fullerton, CA, U.S.A.). The cells were resuspended into $40 \mathrm{ml}$ of TN Buffer (50 mM Tris, $\mathrm{pH} 8.2$, plus $150 \mathrm{mM}$ $\mathrm{NaCl}$ ), and lysed at room temperature at $2,000 \mathrm{lb} / \mathrm{in}^{2}$ with a French pressure cell press (American Instrument Company, Silver Spring, MD, U.S.A.). The lysate was then centrifuged at $4^{\circ} \mathrm{C}$ for $10 \mathrm{~min}$ at 5,000 rpm (JA-14 rotor; Beckman Instruments); the supernatant was transferred to a sterile centrifuge tube and centrifuged at 15,000 rpm (JA20 rotor; Beckman Instruments) for a further $15 \mathrm{~min}$. The resultant pellet was solubilized by a series of urea extractions ( 1 to $10 \mathrm{M})$. Extraction of expressed fusion protein was monitored by separation of proteins on a $12 \%$ SDS-PAGE gel (Laemmli 1970), and visualized by silver staining. Urea extracts containing the fusion protein were dialyzed in TN buffer overnight at $4{ }^{\circ} \mathrm{C}$ to remove excess urea, and stored in 5-ml aliquots at $-80^{\circ} \mathrm{C}$ until further use.

To purify the fusion protein, $\mathrm{TN}$-dialyzed protein extracts were applied to a 1-ml bed volume of GST-Sepharose 4B (Pharmacia Biotech) packed into a 10-ml column (Bio-Rad). The column was rocked on a platform shaker overnight at $4^{\circ} \mathrm{C}$. The column was then extensively washed with TN buffer and the bound fusion protein was eluted with $12 \mathrm{mM}$ glutathione ( $\mathrm{pH}$ 8.2). Glycerol was added to the collected fractions to a final concentration of $15 \%$, and fractions were stored at $-80^{\circ} \mathrm{C}$ until further use.

For the first immunization, a solution containing $1.5 \mathrm{mg}$ of purified GST-GS50 or GST-GS52 protein was emulsified with an equal volume of complete Freund's adjuvant (Sigma), and injected subcutaneously at four sites into a female New Zealand white rabbit. Booster injections were administered four times at 2-week intervals with $1 \mathrm{mg}$ of the fusion protein emulsified in incomplete Freund's adjuvant (Sigma). Blood was collected 14 days after each injection. The preimmune and immune sera were processed (Harlow and Lane 1988) and stored at $-20^{\circ} \mathrm{C}$ in $500-\mu$ l aliquots.

Anti-GST antibodies were removed from the antisera with Immobilized Glutathione S-Transferase (Pierce Chemical, Rock- 
ford, IL, U.S.A.). Five hundred microliters of immune serum was mixed with an equal volume of binding buffer $(0.1 \mathrm{M}$ sodium phosphate plus $0.15 \mathrm{M} \mathrm{NaCl}, \mathrm{pH} 7.2$ ), and loaded onto an immobilized GST column. The column was washed with $24 \mathrm{ml}$ of binding buffer and unbound material collected in 1$\mathrm{ml}$ fractions. Anti-GS50 and anti-GS52 antibodies were further purified with ImmunoPure Immobilized Protein A (Pierce Chemical), according to the manufacturer's specifications.

A final antigen purification of anti-GS50 and anti-GS52 IgG was performed according to the method of Tan-Wilson et al. (1976). Briefly, $0.4 \mathrm{~g}$ of CNBr-activated Sepharose 4B (Sigma) was swollen for $15 \mathrm{~min}$ in $1 \mathrm{mM} \mathrm{HCl}$ and washed on a sintered glass filter with the same solution. The gel was then washed with coupling buffer $\left(0.2 \mathrm{M} \mathrm{NaHCO}_{3}\right.$ plus $0.5 \mathrm{M}$ $\mathrm{NaCl}, \mathrm{pH} 8.5$ ), and transferred to a 5-ml glass culture tube. Fusion protein (1.5 mg; GST-GS50 or GST-GS52) dissolved in coupling buffer was added to the activated Sepharose 4B matrix and mixed end-over-end overnight at $4{ }^{\circ} \mathrm{C}$. Following overnight incubation, the mixture was transferred to blocking buffer (0.2 M glycine, $\mathrm{pH} 8.0)$ and again incubated overnight at $4{ }^{\circ} \mathrm{C}$. The mixture was then transferred to a $10-\mathrm{ml}$ column (Bio-Rad). Excess absorbed protein was removed by washing with $10 \mathrm{ml}$ of coupling buffer, followed by acetate buffer $(0.1 \mathrm{M}$ sodium acetate plus $0.5 \mathrm{M} \mathrm{NaCl}, \mathrm{pH} 4$ ), followed by coupling buffer. Antigen-affinity purification of anti-GS50 or anti-GS52 antibodies was performed as follows: $1.5 \mathrm{mg}$ of protein Apurified IgG (see above) was dialyzed against TN buffer overnight at $4^{\circ} \mathrm{C}$. The sample was then loaded onto the Sepharose 4B-antigen affinity column constructed above and washed with $20 \mathrm{ml}$ of TN buffer. Antigen-specific antibodies were eluted with $5 \mathrm{ml}$ of elution buffer (100 mM glycine, $\mathrm{pH} 2.5$ ), and immediately mixed with $400 \mu \mathrm{l}$ of $1 \mathrm{M}$ Tris ( $\mathrm{pH}$ 8.0) to neutralize the sample. Affinity-purified antibodies were dialyzed overnight at $4^{\circ} \mathrm{C}$ in TBS $(50 \mathrm{mM}$ Tris, $\mathrm{pH} 7.0$, plus 100 $\mathrm{mM} \mathrm{NaCl}$ ), and stored in $100-\mu$ aliquots at $-80^{\circ} \mathrm{C}$.

\section{Western blot analysis.}

To examine the tissue-specific expression of GS50 and GS52, total protein was isolated from 5-day-old roots, hypocotyls, cotyledons, stems, and leaves, from 12-week-old flowers, and from root nodules 15 days postinoculation of $G$. soja plants. Protein extracts were prepared as follows: $1 \mathrm{mg}$ of tissue was homogenized in extraction buffer $(400 \mathrm{mM}$ sucrose plus $10 \%$ glycerol plus $100 \mathrm{mM}$ Tris $(\mathrm{pH} 8.1)$ plus $10 \mathrm{mM}$ EDTA plus $10 \mathrm{mM} \mathrm{KCl}$ plus $1 \mathrm{mM}$ phenylmethylsulfonyl fluoride [PMSF]) with a mortar and pestle. Homogenized samples were transferred to sterile Eppendorf tubes and centrifuged in a microfuge at $16,000 \times g$ for $2 \mathrm{~min}$. The resultant supernatant was removed and mixed with one-quarter-volume $5 \times$ Laemmli sample buffer (Laemmli 1970), and stored at $-80^{\circ} \mathrm{C}$ until further use. The pellet was mixed with $500 \mu \mathrm{l}$ of $5 \times$ Laemmli sample buffer and boiled for $5 \mathrm{~min}$. The sample was then centrifuged in a microfuge at $16,0000 \times g$ and the supernatant stored at $-80^{\circ} \mathrm{C}$ until further use. Proteins were separated by $12 \%$ preparative SDS-PAGE and electrophoresed onto Immobilon-P membranes (Bio-Rad). Following incubation of the membranes with anti-GS50 or anti-GS52 antibodies, the blots were incubated with goat anti-rabbit-IgG alkaline phosphatase conjugated antibody. GS50 and GS52 were then visualized with 5-bromo-4-chloro-3-indolyl phosphate (BCIP) or nitroblue tetrazolium (NBT) as colorimetric substrates. Den- sitometry readings of GS50 and GS52 Western blots were obtained with NIH Image Software (National Institutes of Health, Bethesda, MD, U.S.A.).

\section{Fractionation of soybean root membranes on sucrose density gradients.}

Approximately $200 \mathrm{~g}$ (fresh weight) of 5-day-old roots was used as starting material for membrane isolation. Tissue was homogenized in homogenization buffer $(0.3 \mathrm{M}$ sucrose, 50 $\mathrm{mM}$ 4-morpholineethanesulfonic acid [MES]-Tris [pH 7.6], 5 mM EDTA, $5 \mathrm{mM}$ EGTA, $20 \mathrm{mM} \mathrm{NaF}, 1 \mathrm{mM}$ dithiothreitol [DTT], $4 \mathrm{mM}$ salicylhydroxamic acid [SHAM], $2 \mathrm{mM}$ PMSF, $2.5 \mathrm{mM} \mathrm{Na}_{2} \mathrm{~S}_{2} \mathrm{O}_{5}$, and $0.5 \%$ bovine serum albumin [BSA]) on ice for $30 \mathrm{~min}$. After homogenization, cells were lysed at $1,000 \mathrm{lb} / \mathrm{in}^{2}$ with a French pressure cell press (American Instrument Company). Following lysis, the homogenate was centrifuged at $4,000 \times g$ for $10 \mathrm{~min}$ at $4^{\circ} \mathrm{C}$. The supernatant was then subjected to an additional centrifugation at $4^{\circ} \mathrm{C}$ for $10 \mathrm{~min}$ at $15,000 \times \mathrm{g}$. The resultant supernatant was then centrifuged at $100,000 \times g$ for $1 \mathrm{~h}$ at $4^{\circ} \mathrm{C}$ in a Ti65 fixed angle rotor (Beckman Instruments). After ultra-centrifugation, the microsomal fraction was resuspended in microsomal fraction buffer $(0.25 \mathrm{M}$ sucrose plus $10 \mathrm{mM}$ sodium phosphate, $\mathrm{pH}$ 7.8), and homogenized with a hand-held Potter homogenizer.

After isolation of the microsomal membrane fraction, the membranes were resuspended in $40 \mathrm{ml}$ of gradient medium (50 mM 4-morpholinepropanesulfonic acid [MOPS] [pH 7.5] plus $2 \mathrm{mM}$ EDTA plus $5 \mathrm{mM}$ DTT). An aliquot $(10 \mathrm{ml})$ of each fraction was layered onto four, 20-ml linear 20 to $45 \%$ (wt/wt) sucrose density gradients in gradient medium for isopycnic centrifugation at $100,000 \times g$ at $4{ }^{\circ} \mathrm{C}$ for $3 \mathrm{~h}(\mathrm{SW}-28$ rotor; Beckman Instruments). Following centrifugation, 1.5$\mathrm{ml}$ fractions were collected (bottom to top) with a Versitaltic Pump Plus peristaltic pump (Manostat, New York, U.S.A.) connected to a model 2110 fraction collector (Bio-Rad). The refractive index was determined with an Abbe-3L refractometer (Bausch and Lomb, Rochester, NY, U.S.A.), and sucrose concentrations were determined from a standard curve prepared with known sucrose concentrations. Protein concentrations of membrane fractions were determined with the BCA protein assay (Pierce Chemical), with BSA as a standard.

The following marker enzyme assays were used to identify the membranes found in the various sucrose gradient fractions. For the endoplasmic reticulum (ER): localization of ER membrane fractions was confirmed with a monoclonal antibody specific for calnexin ( $\mathrm{Li}$ et al. 1998). Calnexin monoclonal antibody was a gift from Heven Sze (University of Maryland, College Park, U.S.A.). For the Golgi, latent UDPase activity was determined as follows: $50 \mu \mathrm{g}$ of membrane was added to $50 \mu \mathrm{l}$ of assay buffer ( $3 \mathrm{mM}$ UDP plus $3 \mathrm{mM} \mathrm{MnSO}_{4}$ plus $30 \mathrm{mM}$ MES-Tris, $\mathrm{pH} 6.5$ ), and incubated at $37^{\circ} \mathrm{C}$ for 20 min. Released phosphate was determined by the malachite green method (described below). For the plasma membrane: vanadate-sensitive ATPase assays were conducted immediately after membrane fractionation. Twenty-five microliters of membrane was added to $250 \mu \mathrm{l}$ of ATPase assay buffer $(40 \mathrm{mM}$ Tris-MES [pH 6.75] plus $3 \mathrm{mM} \mathrm{MgSO}$ plus $1 \mathrm{mM} \mathrm{Na}_{2} \mathrm{MoO}_{4}$ plus $10 \mathrm{mM}$ EGTA plus $0.01 \%$ Triton $\mathrm{X}-100)$. The final volume of the reaction was adjusted to $450 \mu \mathrm{l}$ with $\mathrm{dH}_{2} \mathrm{O}$ and incubated at $30^{\circ} \mathrm{C}$ for $3 \mathrm{~min}$. ATP (Tris salt, $3 \mathrm{mM}$ final concentration) was added to the reaction mixture, and the samples 
were incubated for an additional $30 \mathrm{~min}$ at $30^{\circ} \mathrm{C}$. The reaction was stopped by the addition of $50 \mu \mathrm{l}$ of $5 \mathrm{~N} \mathrm{H}_{2} \mathrm{SO}_{4}$. Released phosphate was determined by the malachite green method (described below; Baykov et al. 1989). Vanadate- and nitrate-sensitive ATPase activities were calculated as the difference between the activities with and without the respective inhibitor.

The malachite green method of phosphate determination (Baykov et al. 1989) was as follows: to prepare the color reagent, 3 parts $0.045 \%$ (wt/vol in water) malachite green $/ \mathrm{HCl}$ was mixed with 1 part $4.2 \%$ (wt/vol in $4 \mathrm{~N} \mathrm{HCl}$ ) $\mathrm{NH}_{4}$ molybdate. The mixtures were covered with foil and stirred for $30 \mathrm{~min}$ and then filtered through two No. 1 Whatman filters into a polyethylene container. To $10 \mathrm{ml}$ of this mixture, $200 \mu \mathrm{l}$ of $2 \%$ (wt/vol) tergitol NP (Pierce Chemical) was added. Released phosphate was determined as follows: $800 \mu \mathrm{l}$ of the above mixture was added to 50 to $100 \mu$ of ATPase assay. The mixture was incubated at room temperature for $1 \mathrm{~min}$. After incubation, $100 \mu \mathrm{l}$ of $34 \%$ (wt/vol) sodium citrate- $2 \mathrm{H}_{2} \mathrm{O}$ was added to the reaction, and the mixture was incubated for $1 \mathrm{~h}$ at room temperature. Following incubation, the absorbance was read at $630 \mathrm{~nm}$. Phosphate standards were prepared containing 0 to $30 \mathrm{nmol} \mathrm{P}_{\mathrm{I}}$ from potassium phosphate (monobasic).

\section{RFLP-based mapping of gs52.}

The gs52 gene was mapped in a G. $\max$ cv. Evans $\times$ PI209332 recombinant inbred line [RIL] population. Unfortunately, no polymorphism for $g s 50$ was found in this mapping population and, therefore, it was not mapped. Leaf tissue from 90 lines of an RIL population generated from a cross between Evans and PI209332 followed by single-seed descent through the $\mathrm{F}_{4}$ generation were pooled for bulk DNA extraction and analysis. Plant DNA was extracted and analyzed by the method of Concibido et al. (1996). Parental survey blots containing genomic DNA digested with DraI, EcoRI, EcoRV, HaeIII, HindIII, and TaqI and blotted according to Concibido et al. (1996) were probed with the two apyrase clones. DNA probes of $g s 50$ and $g s 52$ were end-labeled with ${ }^{32} \mathrm{P}$ to a specific activity of $10^{8} \mathrm{cpm}$ of DNA per $\mu \mathrm{l}$. The $g s 52 \mathrm{cDNA}$ was placed on a genetic map of soybean, consisting of 167 RFLP, microsatellite, and amplified fragment length polymorphism (AFLP) marker loci by two-way contingency table analysis with Statview II (Abacus Concepts, Berkeley, CA, U.S.A.) and Mapmaker II software (Lander et al. 1987). Linkage between loci was inferred if the probability of observing a chisquare value was less than 0.001 or if the log of odds ratio (LOD) scored exceeded 3.0. To determine the most likely order of markers, a multipoint analysis was performed in which the favored order of markers exceeded other possible orders by an LOD of 2.0 or greater.

\section{ACKNOWLEDGMENTS}

Research was supported by grant DE-FG02-97ER20260 from the U.S. Department of Energy. Special thanks to Marilyn Etzler for providing the sequence of DB46 prior to publication and Heven Sze for providing the Calnexin antibody.

\section{LITERATURE CITED}

Abeijon, C., Yanagisawa, K., Mandon, E. C., Hausler, A., Moreman, K., Hirschberg, C. B., and Robbins, P. W. 1993. Guanosine diphosphatase is required for protein and sphingolipid glycosylation in the Golgi lumen of Saccharomyces cerevisiae. J. Biol. Chem. 122:307-323.

Altschul, S. F., Madden, T. L., Schaffer, A. A., Zhang, J., Zhang, Z., Miller, W., and Lipman. D. J. 1997. Gapped BLAST and PSI-BLAST: A new generation of protein database search programs. Nucleic Acids Res. 25:3389-3402.

Baykov, A. A., Evtushenko, O. A., and Avaeva, S. M. 1989. A malachite green procedure for orthophosphate determination and its use in alkaline phosphatase-based enzyme immunoassay. Anal. Biochem. 171: 266-270.

Bhuvaneswari, T. V., Bhagwat, A. A., and Bauer, W. D. 1981. Transient susceptibility of root cells in four common legumes to nodulation by rhizobia. Plant Physiol. 68:1144-1149.

Bladergroen, M. R., and Spaink, H. P. 1998. Genes and signal molecules involved in the rhizobia-leguminoseae symbiosis. Curr. Opin. Plant Biol. 1:353-359.

Boutin, S. R., Young, N. D., Olson, T., Yu, Z.-H., Shoemaker, R., and Vallejos, C. 1995. Genome conservation among three legume genera detected with DNA markers. Genome 38:928-937.

Caetano-Anollés, G., and Gresshoff, P. M. 1991. Plant genetic control of nodulation. Annu. Rev. Microbiol. 45:345-382.

Chen, Y.-R., Datta, N., and Roux, S. J. 1987. Purification and partial characterization of a calmodulin-stimulated nucleoside triphosphatase from pea nuclei. J. Biol. Chem. 262:10689-10694.

Chen, Y.-R., and Roux, S. J. 1986. Characterization of nucleoside triphosphatase activity in isolated pea nuclei and its photoreversible regulation by light. Plant Physiol. 81:609-613.

Cohn, J., Day, R. B., and Stacey, G. 1998. Legume nodule organogenesis. Trends Plant Sci. 3:105-110.

Concibido, V. C., Denny, R. L., Lange, D. A., Orf, J. H., and Young, N. D. 1996. RFLP mapping and marker-assisted selection of soybean cyst nematode resistance in PI 209332. Crop Sci. 36:1643-1650.

Cook, D., Dreyer, D., Bonnet, D., Howell, M., Nony, E., and VandenBosch, K. 1995. Transient induction of a peroxidase gene in Medicago truncatula precedes infection by Rhizobium meliloti. Plant Cell 7:43-55.

Cregan, P. B., Jarvik, T., Bush, A. L., Shoemaker, R. C., Lark, K. G., Kahler, A. L., Kaya, N., VanToai, T. T., Lohnes, D. G., Chung, J., and Specht, J. E. 1999. An integrated genetic linkage map of the soybean genome. Crop Sci. 39:1464-1490.

Crespi, M. D., Jurkevitch, E., Poiret, M., d'Aubenton-Carafa, Y., Petrovics, G., Kondorosi, E., and Kondorosi, A. 1994. enod40, a gene expressed during nodule organogenesis, codes for a non-translatable RNA involved in plant growth. EMBO J. 13:5099-5112.

Don, R. H., Cox, P. T., Wainwright, B. J., Baker, K., and Mattick, J. S. 1991. Touchdown PCR to circumvent spurious priming during gene amplification. Nucleic Acids Res. 19:4008.

Edwards, F. A., and Gibb, A. J. 1993. ATP-A fast neurotransmitter. FEBS Lett. 325:86-89.

Etzler, M. E., Kalsi, G., Ewing, N. N., Roberts, N. J., Day, R. B., and Murphy, J. B. 1999. A Nod factor binding lectin with apyrase activity from legume roots. Proc. Natl. Acad. Sci. U.S.A. 96:5856-5861.

Frohman, M. A., Dush, M. K., and Martin, G. R. 1988. Rapid production of full-length cDNAs from rare transcripts: Amplification using a single gene-specific oligonucleotide primer. Proc. Natl. Acad. Sci. U.S.A. 85:8998-9002.

Gao, X.-D., Kaigorodov, V., and Jigami, Y. 1999. YND1, a homologue of GDA1, encodes membrane-bound apyrase required for Golgi Nand O-glycosylation in Saccharomyces cerevisiae. J. Biol. Chem. 274: 21450-21456.

Giannini, J. L., Hotl, J. S., and Briskin, D. P. 1991. The effect of glyceollin on soybean (Glycine $\max \mathrm{L}$.) tonoplast and plasma membrane vesicles. Plant Sci. 74:203-211.

Handa, M., and Guidotti, G. 1996. Purification and cloning of a soluble ATP-diphosphohydrolase (apyrase) from potato tubers (Solanum tuberosum). Biochem. Biophys. Res. Comm. 218:916-923.

Harlow, E., and Lane, D. 1988. Antibodies: A Laboratory Manual. Cold Spring Harbor Laboratory, Cold Spring Harbor, NY, U.S.A.

Heidstra, R., Nilsen, G., Martinez-Abarca, F., van Kammen, A., and Bisseling, T. 1997. Nod factor-induced expression of leghemoglobin to study the mechanism of $\mathrm{NH}_{4} \mathrm{NO}_{3}$ inhibition on root hair deformation. Mol. Plant-Microbe Interact. 10:215-20.

Hseih, H. L., Tong, C. G., Thomas, C., and Roux, S. J. 1996. Lightmodulated Abundance of an mRNA encoding a calmodulin-regulated, chromatin-associated NTPase in pea. Plant Mol. Biol. 30:135-147. 
Kanazin, V., Marek, L. F., and Shoemaker, R. C. 1996. Resistance gene analogs are conserved and clustered in soybean. Proc. Natl. Acad. Sci. U.S.A. 93:11746-11750.

Komoszynski, M., and Wojtczak, A. 1996. Apyrases (ATP diphosphohydrolases, EC 3.6.1.5): Function and relationship to ATPases. Biochim. Biophys. Acta 1310:233-241.

Kouchi, H., and Hata, S. 1995. GmN56, a novel nodule-specific cDNA from soybean root nodules encodes a protein homologous to isopropylmalate synthase and homocitrate synthase. Mol. Plant-Microbe Interact. 8:172-176.

Kouchi, H., Takane, K., So, R. B., Ladha, J. K., and Reddy, P. M. 1999. Rice ENOD40: Isolation and expression analysis in rice and transgenic soybean root nodules. Plant J. 18:121-129.

Lander, E. S., Green, P., Abrahamson, J., Barlow, A., Daly, M. J., and Lincoln, S. E. 1987. Mapmaker: An interactive computer package for constructing genetic linkage maps of experimental and natural populations. Genomics 1:174-181.

Laemmli, U. K. 1970. Cleavage of structural proteins during the assembly of the head of bacteriophage T4. Nature 227:680-685.

Leonard, R. T., and Vanderwoude, W. J. 1976. Isolation of plasma membranes from corn roots by sucrose density centrifugation: An anomalous effect of Ficoll. Plant Physiol. 57:105-114.

Li, X., Su, R. T. C., Hsu, H.-T., and Sze, H. 1998. The molecular chaperone calnexin associates with the vacuolar H+-ATPase from oat seedlings. Plant Cell 10:119-130.

Marcus, A. J., and Safier, L. B. 1993. Thromboregulation: Multicellular modulation of platelet reactivity in hemostasis and thrombosis. FASEB J. 7:516-522.

Minami, E., Kouchi, H., Cohn, J. R., Ogawa, T., and Stacey, G. 1996. Expression of the early nodulin, ENOD40, in soybean roots in response to various lipo-chitin signal molecules. Plant J. 10:23-32.

Nakai, K., and Kanehisa, M. 1991. Expert system for predicting protein localization sites in gram-negative bacteria. Proteins 11:95-110.

Ng, G. Y., Varghese, G., Chung, H. T., Trogadis, J., Seeman, P., O'Dowd, B. F., and George, S. R. 1997. Resistance of the dopamine D2L receptor to desensitization accompanies the up-regulation of receptors on to the surface of Sf9 cells. Endocrinology 138:4199-4206.

Papadopoulou, K., Roussis, A., Kuin, H., and Katinakis, P. 1995. Expression pattern of uricase II gene during root nodule development in Phaseolus vulgaris. Experientia 51:90-94.

Pearson, W. R., Wood, T. C., Zhang, Z., and Miller, W. 1997. Comparison of DNA sequences with protein sequences. Genomics 46:24-36.

Perera, S. C., Ladd, T. R., Dhadialla, T. S., Krell, P. J., Sohi, S. S., Retnakaran, A., and Palli, S. R. 1999. Studies on two ecdysone receptor isoforms of the spruce budworm, Choristoneura fumiferana. Mol. Cell. Endocrinol. 152:73-84

Pichon, M., Journet, E. P., Dedieu, A., de-Billy, F., Truchet, G., and Barker, D. G. 1992. Rhizobium meliloti elicits transient expression of the early nodulin gene ENOD12 in the differentiating root epidermis of transgenic alfalfa. Plant Cell 4:1199-1211.

Polzin, K. M., Lohnes, D. G., Nickell, C. D., and Shoemaker, R. C. 1995. Integration of Rps2, Rmd, and $\mathrm{Pj} 2$ into linkage group $\mathrm{J}$ of the soybean molecular map. J. Hered. 85:300-303.

Roberts, N. J., Brigham, J., Wu, B., Murphy, J. B., Volpin, H., Philips, D. A., and Etzler, M. E. 1999. A Nod factor-binding lectin is a member of a distinct class of apyrases that may be unique to the legumes. Mol. Gen. Genet. 262:261-267.

Sambrook, J., Fritsch, E. F., and Maniatis, T. A. 1989. Molecular Cloning: A Laboratory Manual. 2nd ed. Cold Spring Harbor Laboratory, Cold Spring Harbor, NY, U.S.A.

Sanjuan, J., Spaink, H., Carlson, R., Bhat, R., Glushka, J., Barbour, M., and Stacey, G. 1992. A 2-O-methylfucose moiety is present on the lipo-oligosaccharide nodulation signal of Bradyrhizobium japonicum. Proc. Natl. Acad. Sci. U.S.A. 89:8789-8793.

Sarkis, J. J., and Salto, C. 1991. Characterization of a syntaptosomal ATP diphosphohydrolase from the electric organ of Torpedo marmorata. Brain Res. Bull. 26:871-876.

Scheres, B., Van De Wiel, C., Zalensky, A., Horvath, B., Spaink, H., Van Eck, H., Zwartkruis, F., Wolters, A. M., Gloudemans, T., and Van Kammen, A. 1990. The ENOD12 gene product is involved in the infection process during the pea-Rhizobium interaction. Cell 60:281-294.

So, J. S., Hodgson, A. L., Haugland, R., Leavitt, M., Banfalvi, Z. Nieuwkoop, A. J., and Stacey, G. 1987. Transposon-induced symbiotic mutants of Bradyrhizobium japonicum: Isolation of two gene regions essential for nodulation. Mol. Gen. Genet. 207:15-23.

Stacey, G., Luka, S., Sanjuan, J., Banfalvi, Z., Nieuwkoop, A. J., Chun, J.-Y., Forsberg, L. S., and Carlson, R. 1994. nodZ, a unique hostspecific nodulation gene, is involved in the fucosylation of the lipooligosaccharide nodulation signal of Bradyrhizobium japonicum. J. Bacteriol. 176:620-633.

Tan-Wilson, A. L., Reichlin, M., and Noble, R. W. 1976. Properties of goat anti-human hemoglobin antibodies fractionated on subunit affinity columns. Immunochemistry 13:491-498.

Thomas, C., Sun, Y., Naus, K., Lloyd, A., and Roux, S. J. 1999. Apyrase functions in plant phosphate nutrition and mobilizes phosphate from extracellular ATP. Plant Physiol. 119:543-551.

Thompson, J. D., Higgins, D. G., and Gibson, T. J. 1994. CLUSTAL W: Improving the sensitivity of progressive multiple sequence alignment through sequence weighting, position-specific gap penalties and weight matrix choice. Nucleic Acids Res. 22:4673-4680.

von Heijne, G. 1989. The structure of signal peptides from bacterial lipoproteins. Protein Eng. 2:531-534.

Wacek, T. J., and Brill, W. J. 1976. Simple, rapid assay for screening nitrogen-fixing ability in soybean. Crop Sci. 15:518-523.

Walker, J. E., Saraste, M., Runswick, M. J., and Gay, N. J. 1982. Distantly related sequences in the alpha- and beta-subunits of ATP synthase, myosin, kinases and other ATP-requiring enzymes and a common nucleotide binding fold. EMBO J. 1:945-951. 